\title{
ALGUNAS NOTAS SOBRE LA RECEPCIÓN DE AUTORES GRIEGOS O LATINOS EN LA GENERAL ESTORIA DE ALFONSO X (PRIMERA PARTE). \\ SOME NOTES ON THE RECEPTION OF GREEK OR LATIN AUTHORS IN THE GENERAL ESTORIA OF ALFONSO X (FIRST PART)
}

\author{
JuAN ANTONIO LÓPEZ FÉREZ \\ Universidad Nacional de Educación a Distancia (UNED). Madrid.
}

\section{RESUMEN}

Este trabajo quiere situar cronológicamente las obras y autores griegos o latinos mencionados en la Primera parte de la General Estoria, y, a la vez, añadir algunas aclaraciones sobre los nombres propios de esos escritores, que, con frecuencia, nos han llegado en la obra alfonsí con grafías irreconocibles. En total, la aportación recoge 32 autores griegos y 16 latinos, distribuidos, en lo posible, en orden cronológico. Palabras Clave: Autores griegos, latinos, General Estoria

\section{ABSTRACT}

This work wants to place chronologically the Greek or Latin works and authors mentioned in the First part of the General Estoria, and, at the same time, add some clarifications about the proper names of these writers, which, frequently, have come down to us in the work alfonsí with unrecognizable spellings. In total, the contribution includes 32 Greek and 16 Latin authors, distributed, when possible, in chronological order

KEY WORDS: Greek authors, latin authors, General Estoria

Recibido: 31/07/2020. Aceptado: 30-10-2020.

\section{Generalidades.}

1.1. La General Estoria, redactada entre 1272 y 1284, año de la muerte del rey sabio, pretendía abarcar la historia de la humanidad desde la creación del mundo hasta la época del monarca. Aunque tan magno empeño no pudo cumplirse, pues llegó sólo hasta los años previos al nacimiento de Cristo, lo que nos ha llegado constituye un

\footnotetext{
* Recibido: 31-07-2020 / Aceptado: 30-10-2020.
} 
precioso legado de enorme importancia, vastedad y pluralidad. La obra enriquece los datos traducidos y sacados de la Biblia con los ofrecidos por los escritores más relevantes de la Antigüedad, entre los que figuran en lugar preeminente numerosos latinos y algunos griegos. Los materiales son de muy diversa procedencia, por lo que se tuvo que hacer un gran esfuerzo para traducirlos, $y$, en todo caso, armonizarlos y conseguir un estilo coherente y relativamente unitario. Como el rey confiesa en algunas ocasiones, la General Estoria es una labor de equipo que pasó por diversas revisiones, entre las que destaca la llevada a cabo por él mismo, muy preocupado por la corrección del castellano ${ }^{1}$.

La General Estoria se inserta en el movimiento cultural europeo que siguió al IV Concilio de Letrán (1215-1216). Uno de los efectos de aquél fue la versión de la Biblia al castellano entre los años 1250-1280, y al francés, algo más tarde. La General Estoria contiene la segunda traducción castellana, no literal, de la Vulgata latina de San Jerónimo. Unas décadas antes, se había redactado la llamada Biblia prealfonsina, que, en dos códices, se conserva en la Biblioteca de El Escorial: abarca parte del Antiguo Testamento y casi todo el Nuevo.

De entre la GE, me concentraré en la Primera parte, donde se abordan los hechos bíblicos contenidos en el Pentateuco, desde la creación del mundo hasta la muerte de Moisés (Génesis-Éxodo-Levítico-Números-Deuteronomio). Aparte de la Biblia, los redactores de dicha parte recurrieron con frecuencia a las fuentes judías y, asimismo, a las obras de numerosos autores griegos o latinos, entre otros.

1.2. Mi propósito es situar cronológicamente las obras y autores griegos o latinos mencionadas en la indicada parte de la $G E$, y, a la vez, detenerme brevementecon algunas aclaraciones. La meritoria edición de la GE, única completa de la obra, aparecida en 2009², presenta algunas veces los nombres de autores clásicos (especialmente griegos) con grafías que los hacen irreconocibles. Precisamente esta aportación mía quiere animar a la colaboración entre estudiosos hispanistas y clasicistas. En total recojo 32

1* Elaborado dentro del Proyecto FFI2017-82850-R del Ministerio español de Economía, Industria y Competitividad.

FERNÁNDEZ ORDóÑEz (1999), pp. 105-126, demuestra que las escuelas alfonsíes trabajaron desde 1250 hasta la muerte del rey sabio; que hacia 1270 se gestó el proyecto concreto de redactar tanto la Estoria de España como la General Estoria; y que las dos obras recurren a las mismas traducciones de las fuentes (entre ellas, Plinio, Ovidio, Lucano, Pompeyo Trogo, Justino, Orosio, Eusebio-Jerónimo, Sigeberto de Gembloux, Lucas de Tuy, Hugucio, Jiménez de Rada, etc.). De la misma estudiosa, véanse, entre otros, 1989, 1992. Relevante para nuestro estudio ha sido, entre muchos, LIDA DE MALKIEL (1958-1959; 1959-1960).

${ }^{2}$ Alfonso X el Sabio, General estoria, Pedro Sánchez-Prieto (coord.), Madrid, Fundación José Antonio de Castro (Biblioteca Castro), 2009 (la Primera parte, en dos volúmenes había aparecido ya en 2001). Para esta contribución me atengo a la Edición de textos alfonsíes en Real Academia Española: Banco de datos (CORDE) [en línea], primera parte, por P. Sánchez-Prieto Borja-R. Díaz Moreno-E. Trujillo Belso. Cf. Bibliografía. En las citas que doy aparecen tres datos: parte de la obra (en romanos), libro y capítulo (en cifras arábigas). 
Algunas notas sobre la recepción de autores griegos o latinos en la General Estoria de Alfonso X [...]

autores griegos y 16 latinos, distribuidos, en lo posible, en orden cronológico ${ }^{3}$. Veremos algunas deformaciones de varios antropónimos, especialmente de autores griegos, recogidos y aceptados en el útil índice de nombres propios de dicha parte de la $G E^{4}$.

\section{Autores de literatura griega}

Nuestra aportación abarca, dentro de la parte estudiada de la GE, escritores de la literatura griega desde el siglo VIII a. C. (periodo arcaico) hasta mediados del IV d. C. (periodo imperial).

\subsection{HOMERO (2)}

2.1.1. Su momento de esplendor suele situarse en los últimos decenios del VIII a. C. En el corpus revisado contamos con dos menciones de ese autor. En el primer caso, a propósito de Etiopía, se nos dice: «E Omero, que fue muy grand sabio entre todos los griegos, afirma que verdaderamientre dos son las Etiopias ${ }^{6}[. .$.$] e que allí se fazié un$ río que nace, así como vos contamos, del Nilo [...] e llámanle Nigris [...]»7 .

La GE sigue en este punto a Plinio (gran fuente de dicha obra), pero, a decir verdad, Homero no menciona nunca el corónimo Etiopía.

2.1.2. La segunda mención alfonsí la hallamos en un contexto donde se nos ofrece una verdadera acumulación de fuentes. Efectivamente, a propósito de cómo nace el Nilo y los lugares por donde pasa, se nos dice en la GE: «Del Nilo cómo nace e de los logares ó parece e por ó passa fablaron muchos sabios, assí como Aristótil e Tolomeo e Plinio, Eratesten e Homero 9 e Temosten e Artemidoro e Esidoro e Muciano e Lucano e Paulo Orosio» ${ }^{10}$.

\footnotetext{
${ }^{3}$ Tras el nombre del autor doy entre paréntesis el número de apariciones dentro de la Primera parte de la GE.

${ }^{4}$ Cf. B. Almeida Cabrejas (2015), publicado a partir de la edición de Sánchez-Prieto y otros aparecida en 2001 en la Fundación José Antonio de Castro y reeditada en 2009. Lo mencionaremos como «Índice».

${ }^{5}$ Acerca de su presencia en Alfonso X y en la GE, cf. EISENBERG (1973), SAQuERo SuÁrEZ-Somonte-GonzÁLEZ Rolán (1993), López Férez (1994), Casas Rigall (1999, 1999A), Peláez Benítez (1999), Del Castillo LEBOURGEOIS (2015), CRISTóBAL (2015); etc

${ }^{6}$ Aparece 79 veces en la 1̊parte; además, 'etiopianos', 14; y 'etiopissa', 13.

${ }^{7}$ GE I 11.39.

${ }^{8} \mathrm{NH} 5.43$.

${ }^{9}$ No aparece en Homero (Sí en Hesiodo: Th. 338), ni en Artemidoro. Sí en Aristóteles, Eratóstenes y Ptolomeo.

${ }^{10}$ GE I.5.7.
} 
Esta secuencia es de extremo interés para nuestro propósito a causa de los muchos autores mencionados, que iremos viendo poco a poco. Revisando los nombres citados, conviene insistir en que el Nilo no aparece en Homero. Sí en los demás escritores griegos (en orden cronológico, Aristóteles, Eratóstenes, Timóstenes, Artemidoro y Ptolomeo), así como en los cinco latinos allí citados. Nos ocuparemos de ellos en el lugar oportuno.

\subsection{Hesíodo $(1)^{11}$.}

Para muchos cabe situar su nacimiento algo después que el de Homero. En la parte revisada de la GE sólo contamos con una cita segura. Se trata del momento en que la obra alfonsí menciona a Josefo con referencia al «saber de la astrología e de la geometría e de todos los saberes liberales», diciendo así:

Onde aduze Josefo por exiemplo ende a Manicón, que escrivió las estorias de los egipcianos, e a Beroso, que las de los caldeos, e a Maço, e a Esto, e a Jerónimo de Egipto, que escrivió la estoria de la cibdat Feniça, segund avemos dicho, e otrosí Esiodo e Agateo e Belenico e Acusilao e Efero e Nicolao. Todos estos fazen en sus estorias remembrança d'aquellos antigos cómo algunos d'ellos visquieron mil años, e algunos poco menos ${ }^{12}$.

Se trata de una cita tomada de Josefo, Antiquitates Iudaicae $(A I)$ 1. 108. Leyendo a Josefo vemos que, en la GE, Agateo es Hecateo, y Belenico, Helanico, recogidos sólo aquí en el corpus alfonsí revisado. Y que Manicón es Manetón; Maço, Moco (de Mochus); Esto, Hestieo; Esiodo, Hesíodo; Efero, Éforo. Por su parte, Beroso, Jerónimo de Egipto, Acusilao y Nicolao están bien.

\subsection{TAles de Mileto (1).}

Vivió aproximadamente entre 624-546 a. C. A propósito de la Osa Menor, y tras haberse mencionado poco antes a Ovidio, leemos:

Dize otrossí esse esponedor ${ }^{13}$ que aquello por que la menor Ossa á nombre Fenice que se deve esto catar que ovo ella aquel nombre segund era llamado aquel que la primero figuró en el cielo, e éste fue un sabio a que dixieron Melesio Tales, que fue de Filoseo, e esto es de Mileo, que era una cibdad de Fenicia que avié assí nombre. E este Milesio Tales figuró peró que otra estrella era en el cielo la menor Ossa, e porque era él de Fenicia

11 De su presencia en la GE se han ocupado LóPEz FÉRez (2014), ALMEIdA CABREJAS (2016), GómEZ JimÉnez (2018, pp. 173-193), etc.

$12 G E$ I 2.7. Parte de los errores de transcripción de la $G E$ se deben a que el texto latino (cf. el ofrecido en The Latin Josephus Project) ya contenía importantes desviaciones respecto a la grafía griega.

${ }^{13}$ Un punto no resuelto todavía es de qué comentarista se está hablando aquí. Se duda entre Juan de Garland y Arnulfo de Orleáns. 
Algunas notas sobre la recepción de autores griegos o latinos en la General Estoria de Alfonso X [...]

dixieron a la menor Ossa Fenice e Fenicea, ca a la mayor Ossa los griegos la avién ya figurada ${ }^{14}$.

En el pasaje alfonsí hay un error de bulto al indicar que 'Mileo' (es decir, Mileto) era una ciudad de Fenicia, seguramente con el deseo de convertir a Tales en un nacido en tal lugar.

\subsection{Helanico (1).}

Logógrafo cuyo momento culminante tuvo lugar hacia el 500 a. C, 1lamado «de Lesbos» (o «de Mitilene»), brilló hacia el 500 a. C. La GE en la $1^{\text {a }}$ parte lo cita sólo una vez, pero con una grafía deformada y casi irreconocible, a saber, como Belenico ${ }^{15}$. Véase apartado 2.2.

\subsection{Acusilao (1).}

Acusilao de Argos fue un logógrafo y mitógrafo griego que en torno al 500 a. C. escribió tres libros de genealogías de los que nos han llegado algunos fragmentos. Véase apartado 2.2.

\subsection{EURÍPIDES $(1)^{16}$.}

El más joven de los tres grandes tragediógrafos atenienses vivió entre los años 484-406 a. C. En la GE, hablando de Atlas, hermano de Prometeo, con respecto a que llevaba sobre sí todo el cielo, se nos dice:

Sobresto dize un sabio que ouo nombre Euripides, segund cuenta Eusebio e Jheronimo, que en Affrica a un mont muy alto ademas e quel dizien otrossi el mont Athlant; e tan bien daquello que dixieron del rey Athlant como daquel mont muy alto, fablaron mucho los auctores delos gentiles en muchos logares en sus libros, como Ouidio, e Virgilio, e Estacio e Oracio e otros; onde uos queremos en este logar, por esta razon, contar daquel mont Athlant unas razones que fallamos dichas de Plinio e de otros sabios quales razones e quan estrannas oyredes agora aqui ${ }^{17}$.

\footnotetext{
${ }^{14}$ GE I.21.14.

${ }^{15}$ Así, en «Índice», 2015.

${ }^{16}$ Del lejano reflejo de Eurípides en la GE se han ocupado GómEz Fariña (2014), CRistóbal (2015), LAURIOLA-DEMETRIOU (2015, p. 511), LóPEZ FÉREZ (2015), etc.

${ }^{17}$ GE I 10.21. Contamos con tres citas de Atlas en las obras euripideas: Hipp.747, HF 405, Io. 1. No obstante, la GE parece haber tomado la referencia de la Historia de todas partes (Pantodapè historía) de Eusebio de Cesarea, dividida en dos partes: la Cronografía, resumen de historia universal, y los Cánones cronológicos, donde los datos históricos se ofrecían en columnas paralelas. Esta parte fue conservada por Jerónimo y se le da el título de Chronicon. En éste (pp.50-51) leemos así: Atlas frater Promethei praecipuus Astrologus dictus est, qui ob eruditionem istius disciplinae etiam coelum sustinere affirmatus est. Euripides autem montem esse altissimum dicit, qui Atlas vocetur. El orónimo-teónimo lo hallamos también en Virgilio, Eneida 1.741, 4.481, 6.796, 8.136.140.141; Ovidio, Met. 2.296, 6.174; etc. Véanse, asimismo, Horacio,
} 
Como se ve, si hasta ahora la fuente esencial ha sido Josefo, en este texto se acude a Jerónimo, que, a su vez, recurre con frecuencia a Eusebio.

\subsection{Platón (5) $)^{18}$.}

La vida del filósofo suele enmarcarse entre los años 427-347 a. C. En la parte estudiada de la GE lo hallamos cinco veces. En la primera lo leemos a propósito de las palabras dirigidas por César al obispo Acoreo $^{19}$ : «E dinos esto e manifiéstanos en todo lo que es, e muéstranos los dioses que más quieren ser conocidos de los omnes e onrados d'ellos, e si verdad es lo que fallamos escrito que los tus mayores enseñaron las sus cosas santas a Platón de Atenas el filósofo, enseña tú a mí esto ${ }^{20}{ }_{\gg}{ }^{21}$.

Las otras cuatro aluden a la presencia de la peste dentro de la obra platónica ${ }^{22}$.

\section{8. ÉFORO (1).}

Éforo de Cime (aprox. 400-330 a. C.) fue un historiador griego conocido especialmente por su historia universal en 29 libros, de los que sólo nos han llegado fragmentos. En la citada obra se abarcaba desde los años míticos de los Heraclidas (sc. los hijos y sucesores de Heracles) hasta el 340 a. C. En la GE lo leemos como Efero: acúdase al apartado 2.2.

\subsection{Aristóteles (11: Aristótil, 10; Aristotótil, 1)²3.}

Ya hemos visto al filósofo (384 a. C.-322 a. C) como una de las autoridades que se habrían ocupado de dónde nació el Nilo y por dónde pasa ${ }^{24}$.

Carmina 1.10.1; 1.34.11; Estacio, Tebaida 1.98; 5.430; 7.4; 8.315; Silvae 1.1.60; 4.2.19; 4.3.157.

${ }^{18}$ Sobre el reflejo del filósofo en Alfonso X, y, de modo especial, en la GE: LIDA DE MALKIEL (1959-1960), RICO (1972, p. 137), Eisenberg (1973), Alvar (2010, pp. 289, 377), TAYlor (2015), etc.

${ }_{19}$ Personaje mencionado por Lucano, $B C$ 8.475; 10.193. Era el sacerdote que en Menfis controlaba las crecidas del Nilo.

${ }^{20}$ Cf. Lucano, BC 10,179-183. La GE ofrece casi una traducción de la secuencia.

${ }^{21}$ GE I.5.10. El texto apunta a un tema de gran importancia: cómo los saberes egipcios pasaron a Grecia gracias a Platón.

${ }^{22}$ GE I.13.4, I.13.14, I.13.15, I.13.20.

${ }^{23}$ En torno al reflejo de Aristóteles en Alfonso X, y, ante todo, en la GE, acúdase a Rico (1972, pp.122, 126, 144), Montoya (1995), Alvar (2010, pp. 289, 377), Cristóbal (2015); PÉrez Herranz (2016, pp. 74, 108), etc.

${ }^{24}$ Véase nuestro apartado 2.1.2. 
En otro lugar la GE, al ocuparse de cómo Abrahán supo qué era Dios, recurre al filósofo cuando establece una cierta semejanza entre el hombre y Dios; aquél, como participante en la gloria de Éste ${ }^{25}$.

A su vez, en la GE advertimos un interés manifiesto por los cruces sexuales de animales distintos ${ }^{26}$. Se recurre a Plinio ${ }^{27}$, que tomó los datos a partir de Aristóteles, y, asimismo, de otros muchos sabios, sin especificar. El naturalista romano nos cuenta en otro lugar que el estagirita, por petición de Alejandro, estuvo estudiando durante mucho tiempo las naturalezas de los animales y que compuso $50 \operatorname{libros}^{28}$ con los resultados.

\subsection{HeCATEO (3)}

El «de Abdera» o «de Teos», historiador griego del siglo IV (no debemos confundirlo con el homónimo «de Mileto», historiador y geógrafo de fines del VI y comienzos del V). Contemporáneo, más o menos, de Alejandro Magno, acompañó a Ptolomeo I en varias ocasiones, en una de las cuales viajó con él por el Nilo, río arriba. Fue autor de unos Egipciacos, o relatos referentes a Egipto, conocidos sólo por fragmentos. Según Josefo, que lo cita en 10 ocasiones, fue autor también de un libro relativo a los judíos, muy discutido. Un error importante de la GE es afirmar ${ }^{29}$ que ese relato se habría escrito en árabe, y que no habían encontrado una traducción del mismo al latín.

La GE, $1^{\text {a }}$ parte, lo recoge bien como Agateo ${ }^{30}$, bien como Ecateo, o como Etateo. Respecto a Agateo, véase nuestro apartado 2.2.

Los fragmentos de dicho Hecateo han sido muy discutidos y estudiados porque para muchos es el primer griego que se ocupó de los judíos y, en concreto, de Abrahán.

${ }^{25} G E$ I.4.32. Hallamos en el estagirita notables secuencias donde se establecen las diferencias entre el 'hombre' (ánthrōpos) y el 'dios' (theós): cf. EN 1123a7; 1145a21; 1178b24; etc.

${ }^{26} \mathrm{GE}$ I.20.9. En el capítulo se menciona siete veces al filósofo, verdadera acumulación del antropónimo.

${ }^{27} \mathrm{NH} 8.16$.

${ }^{28}$ En la GE I.20.9 se habla de un pasaje de Plinio donde se trataría de un escrito de Aristóteles, con cincuenta libros, dedicado a los animales ( $N H$ 8.44: quos percunctando quinquaginta ferme volumina illa praeclara de animalibus condidit), número exagerado.

${ }^{29}$ GE I.4.8.

${ }^{30}$ Así, en «Índice...» (2015), sin relacionarlo con Hecateo; dicho instrumento se interroga, en cambio, si Etateo corresponde a dicho antropónimo. 


\subsection{TEOFRASTO (1).}

Su vida transcurrió en los años 371-287 a. C. Director del Liceo a la muerte de Aristóteles, quien lo nombró para el cargo, fue autor de una obra amplísima, mal transmitida. Quizá lo más relevante de lo conservado pueden ser sus obras de botánica. En la GE, parte revisada, lo tenemos como Teorasto, mencionado a propósito de los resultados de la mezcla sexual de los animales, un punto al que se le confiere especial importancia en la obra alfonsí. Leemos así: «Teorasto el sabio fizo creer al pueblo, segund retrae Plinio, que en Capadocia que las mulas paren, e que se son allí de su natura e non d'otra» ${ }^{31}$. Pasaje donde leemos otras informaciones curiosas, como que el mulo o la mula que dan coces se calman si las hartan de vino; y, además, que, en una ocasión, una yegua, de su unión con un mulo, quedó preñada y tuvo un mulo pequeño, según Plinio.

\subsection{Beroso (5) ${ }^{32}$.}

Vivió quizá en los años 350-270 a. C.; escribió en la koiné griega y fue autor de unos Caldaicos en tres libros: en ellos abarcaba desde los orígenes de Babilonia hasta el reinado de Antíoco I. Se le atribuyen otras obras, pero, para muchos, espurias. Su legado literario fue importante durante el periodo helenístico. No nos corresponde hablar del Pseudo-Beroso, al que se le atribuye un famoso escrito falsificado por Anio de Viterbo $^{33}$ en 1498.

La GE, en la parte abarcada por esta aportación, lo recoge en cinco pasajes. Por su lado, Josefo lo cita 12 veces. Se le nombra en la GE con referencia al arca de Noé:

E los sos sabios que escrivieron en su tierra las estorias de los fechos que ý acaecieron fablaron d'este diluvio e d'esta arca en sus leyendas bárbaras, e assí lo otorga Josefo. E fue ell uno de los escrividores d'estas estorias Beroso el caldeo, e llama naf a esta arca de Noé. E dixo ende assí d'aquella naf que vino en Armenia e posó cerca'l mont Cordiceo, e que aun á ý d'ella, e que algunos van allá por d'aquel bitumen con que ella fue untada, que es muy bueno pora lavar e toller toda manziella de quequier ${ }^{34}$.

También se le menciona dos veces a propósito de Abrahán ${ }^{35}$.

\footnotetext{
${ }^{31} G E$ I.20.26.

${ }^{32}$ Algunos estudios se han referido a la presencia de Beroso en la GE: EIsEnBERg (1973), González DíAz (2014, PP. 74-78), LóPEZ FÉREZ (2014), etc.

${ }^{33}$ Éste, con referencia a España, inventó una lista de reyes que remontaban hasta Túbal, hijo de Jafet, un hijo de Noé.

${ }^{34}$ GE I 1.6. Cf. Josefo, AI 1.93.

${ }^{35}$ GE I.4.8. Véase Josefo, $A I 1.158 ;$; $G E$ I.4.14. Cf. Josefo, $A I 1.158$.
} 
2.13. MANETÓN (1).

El citado suele fecharse entre 323-250 a. C. Fue un sacerdote egipcio que vivió en la época de los dos primeros ptolomeos y escribió, en griego, unos Egipciacos en que recogió la cronología de las diversas dinastías desde los comienzos hasta Alejandro Magno. Esa obra histórica nos es conocida sólo de forma fragmentaria gracias a Josefo y otros historiadores.

En la sección revisada de la GE consta sólo una vez, como Manicón ${ }^{36}$ : cf. apartado 2.2.

\subsection{Timóstenes (2).}

Timóstenes de Rodas, geógrafo griego de las primeras décadas del siglo III a. C., trabajó al servicio de Ptolomeo II Filadelfo, y escribió una obra titulada Sobre los puertos, en diez libros, perdida para nosotros ${ }^{37}$.

La GE, en el corpus revisado, lo presenta como Temosten ${ }^{38}$ (ya visto en el apartado 2.1.2) y Temostem, como ahora leeremos: «Sobr'este departimiento cuenta Plinio en el dozeno capítulo del quinto libro de la Natural estoria ó éll e estos otros sabios Temostem, e Eratostem, e Artenidor e Esidoro fablan de Egipto cuamaña es e cómo tajada segund que el río Nilo la fiende e la cerca» ${ }^{39}$.

\subsection{ERATÓstenes (2).}

Natural de Cirene (276-195/194 a. C), gran sabio de conocimientos universales, fue Director de la Biblioteca del Museo de Alejandría. En esta ocasión nos interesan ante todo sus Geográficos en tres libros, perdidos casi por completo, en que estudiaba el mundo entonces conocido. Se le tiene por fundador de la Geografía, de tal modo que buena parte de su terminología dentro de esa materia sigue todavía en uso. Con respecto a las menciones de la GE en la parte revisada, Estrabón y Proclo nos ofrecen, cada uno de ellos, dos testimonios de la relación de Eratóstenes con el Nilo. Además, según datos ofrecidos por el TLG, otros siete contextos de autores varios nos permiten ver el interés de dicho sabio por Egipto.

\footnotetext{
${ }^{36}$ Así, en «Índice» (2015).

${ }^{37}$ Véase Estrabón, 9.3.10. Timóstenes estuvo, escribió y trabajó como geógrafo en Egipto. En él pudo basarse Plinio para citarlo en relación con dicho país.

${ }^{38}$ Tanto este antropónimo como el siguiente figuran en «Índice» (2015), que no los relaciona entre sí.

${ }^{39}$ GE I.7.7. Plinio, HN 5.47 es aquí la fuente de la Estoria.
} 
La GE, sección estudiada, lo presenta con las grafías Eratesten ${ }^{40}$ (apartado 2.1.2), y Eratostem (apartado 2.12).

\subsection{MnASEAS (2) ${ }^{41}$.}

Parece tratarse de Mnaseas de Patara (o Patras), que fue discípulo de Eratóstenes, en Alejandría, vivió hacia fines del III a. C., y escribió un Periplo sobre Europa, Asia y África, en seis u ocho libros, así como unos Oráculos con respuestas comentadas. Sólo nos han llegado escasos fragmentos. Sus escritos no tenían una orientación historicista, sino que abundaban en elementos fantasiosos o claramente falsos.

En la parte estudiada de la GE lo leemos con dos grafías diferentes dentro del mismo contexto: Manaseas y Maniseas:

Otrossí Jerónimo de Egipto, que escrivió la estoria de la Antigüedat de Feniça, la cibdat de Egipto que pobló Feniz, hermano de la reína Europa e del rey Cadmo, e fijo del rey Agenor, fabló otrossí del fecho d'este diluvio e d'esta arca, e otrosí Maniseas de Damasco en el LXXXX ${ }^{\mathrm{a} V I^{\circ}}$ libro de sus estorias dixo d'esta arca assí: un mont muy alto á en tierra de Armenia sobre tierra de Numiada, e el mont á nombre Baris. E a este monte dizen que fuxieron muchos sobre Numiada e se libraron allí del periglo de la muerte del diluvio general, e vino ý otrossí uno aducho en una arca, e posó con ella en somo lo más alto del mont Ocile, e allí fincaron mucho tiempo las remasajas de los maderos d'aquell arca, e aun éste fue aquel de quien Moisén, que dio la ley de los judíos, fabló en su estoria e lo escrivió. E d'esta guisa fablaron d'este diluvio e del arca Beroso de Caldea e Jerónimo de Egipto, e Manaseas de Damasco ${ }^{42}$.

El texto se basa esencialmente en Godofredo de Viterbo, Pantheon pars 2.82, con curiosas diferencias.

\subsection{Polibio (4).}

El gran historiador griego de época helenística vivió en los años 200-118 a. C. En la primera ocasión se le cita en relación con el monte Atlas y el río Anatis ${ }^{43}$ (con dos menciones); la segunda está dedicada al comportamiento de los leones ${ }^{44}$ (también con dos referencias).

\footnotetext{
${ }^{40}$ Esta denominación y la siguiente las ofrece el «Índice» (2015), donde no se las conecta.

${ }^{41}$ Sobre la presencia en la GE, cf. EISENBERG (1973).

${ }^{42} G E$ I.2.6.

${ }^{43} G E$ I.10.25.

${ }^{44} G E$ I.20.10. El texto sigue, en general, a Plinio, $H N$ 8.48-52.
} 
2.18. Crates de Malo (1).

Floreció en la primera mitad del II a. C. Procedente de Malo (Cilicia) tuvo gran importancia en la corte de Pérgamo, hasta tal punto que Plinio (HN 7.13) le llama «Crates de Pérgamo». Fue relevante como gramático y crítico literario, actividades en que siguió las orientaciones estoicas. La GE lo cita a propósito de las serpientes venenosas:

Peró un sabio que ovo nombre Crates de Troya, que fabló de la natura de los omnes e de las serpientes, cuenta que en una isla de septentrión que dizen ellos Ponton á otrossí un linage de omnes, e llámanles los ofiogenes, e diz que éstos an natura que si tañen la ferida dell omne que la serpiente le faze que sana, e si ponen la mano en el ferido desque ell empoçonamiento viene a venino que gelo sacan del cuerpo e guarecen ${ }^{45}$.

\subsection{AgatÁrQuides de CNido (2).}

Fue un historiador, geógrafo y filósofo del II a.C. Vivió aproximadamente entre los años 215-145 a. C. Escribió un tratado sobre los asuntos de Asia (10 libros), otro acerca de los pertinentes a Europa (49 libros), y otro titulado Del mar rojo, distribuido en cinco libros. Plinio lo cita tres veces. Las dos menciones presentes en la parte estudiada de la GE las leemos en el mismo pasaje, a propósito de un pueblo de África llamado, en plural, los psilos, que mataban a las serpientes con el veneno de sus cuerpos ${ }^{46}$. Figura en la GE como Agarchachides ${ }^{47}$.

\subsection{LOS SETENTA ${ }^{48}$.}

Los así llamados - entre el 280, comienzo de sus trabajos, y el 100 a. C., fin de la versión, y durante varias generaciones - tradujeron al griego (koinê) los 44 libros de la Biblia hebrea y aramea. La versión de los Setenta ${ }^{49}$ abarcó también libros que para algunos son apócrifos. La traducción la había propuesto Ptolomeo II, Filadelfo, y los

\footnotetext{
${ }^{45} G E$ I.8.15. La obra alfonsí se basa en Plinio, $H N$ 7.13. Lo de «una isla de septentrión que dizen ellos Ponton», correspondería en Plinio, realmente, a «en los alrededores de Pario» (Crates Pergamenus in Hellesponto circa Parium genus hominum fuisse, quos Ophiogenes vocat, serpentium ictus contactu levare solitos et manu inposita venena extrahere corpori). Notemos, además, que el «Crates Pergamenus» del naturalista romano se ha transformado en «Crates de Troya».

${ }^{46}$ GE I.8.15.

${ }^{47}$ Así en «Índice» (2015).

${ }^{48}$ Cf. EISENBERG (1973), Francomano (2011: sobre el proceso seguido en la GE para romancear, prosificar y glosar la Biblia). Respecto a cómo la $G E$ creó un nuevo vocabulario, adaptando el léxico latino al sistema fonético y rítmico del castellano, véase MoRREALE (1969).

${ }^{49}$ En la $G E$, dentro de la sección estudiada, son citados como «los LXX» (33 veces; de ellas, 24, junto a «Trasladadores»), y «los Setaenta/Setenta Trasladadores», 21 secuencias; además, sólo como «Los trasladadores», cuatro veces. Nótese una preferencia evidente por la versión más breve: «los LXX». Por otra parte, el total de apariciones del calificativo «Trasladadores» es de 49.
} 
traductores fueron realmente, en un primer momento, 72, enviados a Alejandría por el Gran sacerdote de Jerusalén.

La GE recurre a ellos, en paralelo y contraste con otras cronologías, al fijar los años que duró la primera edad (desde Adán hasta Noé), la segunda (desde Noé hasta Abrahán $)^{50}$ y la tercera (desde Abrahán hasta el último año del rey Saúl y primero del rey David $)^{51}$. Se tienen en cuenta también los datos de la versión hebrea, y se menciona en ocasiones lo afirmado por «maestre Pedro en el Libro de las generaciones del Viejo Testamento» ${ }^{52}$. El contraste entre lo afirmado en la versión hebrea y lo suministrado por los Setenta se ofrece también a propósito de la muerte de $\operatorname{Jacob}^{53}$ y de la muerte de José $^{54}$.

\subsection{Artemidoro de ÉFESO (2).}

Geógrafo griego del siglo I a. C., autor de un tratado en once libros, titulado Geografía, del que tenemos conocimiento por Estrabón. Es citado varias veces por Plinio. No hay que confundirlo con otro Artemidoro de Éfeso, del II d. C., responsable de un tratado de interpretación de los sueños.

En la parte estudiada de la GE ya lo hemos visto en el apartado 2.12 como Artenidor $^{55}$. Y también como Artemidoro, en nuestro apartado 2.1.2.

\subsection{Alejandro Polihístor (2).}

Cornelio Alejandro Polihístor, gramático e historiador griego que obtuvo de Sila la ciudadanía romana, llegó a Roma como prisionero de guerra a comienzos del s. I a. C. Fue autor prolífico de escritos de contenido diverso (de ahí el apelativo de origen griego, Polihístor, es decir, «el que relata (o cuenta) muchas cosas»), etnografías y curiosidades de Oriente, que quería dar a conocer en la capital. Dos veces seguidas lo leemos en un pasaje referente al casamiento de Abrahán, tras la muerte de Sara, con Cetura $^{56}$, y asimismo a los hijos habidos con ella ${ }^{57}$.

\footnotetext{
${ }^{50}$ Para estas dos primeras edades, véanse GE I.3.1 y I.10.2, con dos menciones de «los LXX».

${ }^{51} G E$ I.10.3.

${ }^{52}$ GE I.3.1. Abarca también la paráfrasis latina realizada por Pedro Coméstor, hacia 1170, en su Historia Scholastica.

${ }^{53}$ GE I.9.39. Con cuatro referencias de «los LXX».

${ }^{54}$ GE I.9.47. Vemos cuatro alusiones de «los LXX».

${ }^{55} \mathrm{El}$ «Índice» (2015) lo presenta así, como autor distinto de Artemidoro.

${ }^{56}$ La Agar de la Biblia.

${ }^{57}$ GE I.6.16.
} 


\subsection{Nicolás de Damasco (2).}

Fue un historiador sirio que vivió en los años del emperador Augusto. Compuso una historia universal en 144 libros, de la que sólo nos han llegado unos pocos fragmentos. También dejó una autobiografía, una vida de Augusto y algunos textos filosóficos. Josefo lo cita con cierta frecuencia.

A propósito de la Pentápolis bíblica, Sodoma y Gomorra entre ellas, la GE nos dice:

Josepho cuenta enel seteno capitulo que moro Abraham en tierra de Canaan enla cibdad de Damasco; e un diz que, fasta este dia de oy, a en Damasco un barrio quel dizen la morada de Abraham, e aun quelos que y moran que se precian por ello e se tienen por mas nobles ${ }^{58}$. Onde dize enel quarto libro de sus Estorias Nicolao de Damasco, que fue un sabio de aquella tierra que escruio las estorias della: Abraham uiniendo auenedizo son su hueste dela tierra delos caldeos, que yaze sobre Babilonna ${ }^{59}$, regno en Damasco ${ }^{60}$.

Ya lo hemos visto nombrado simplemente como Nicolao ${ }^{61}$. Cf. el apartado 2.2.

\subsection{ISIDORO DE CÁRACE (2).}

Isidoro de Cárace fue un geógrafo de la época del emperador Augusto, autor de una obra titulada Estaciones partas, no conservada y redactada en griego, donde recogía un itinerario del camino que unía Antioquía con la India, pasando por las sucesivas estaciones, o paradas, donde se detenían las caravanas que marchaban por esa ruta. Plinio lo cita bastante, pues Augusto seleccionó al indicado para que recogiera toda la información posible sobre el oriente, especialmente de Armenia y del territorio de los partos y árabes, pues hacia esos lugares iba a hacer una campaña militar Gayo César, un nieto del emperador (realmente, hijo adoptivo del mismo), que moriría durante la misma.

La GE lo cita como Esidoro ${ }^{62}$ : cf. apartados 2.1.2; 2.12.

\subsection{JERÓNIMO EL EGIPCIO (3).}

Josefo $(A I 1.94 ; 107)$ lo menciona dos veces, considerándolo autor de la historia antigua de Fenicia. El autor judío es el primer escritor de obra conservada que lo

\footnotetext{
${ }^{58}$ Acerca de ese relato, véase Josefo, AI 1.160. Por lo demás, dicho historiador judío cita a Abrahán 31 veces en sus obras.

${ }^{59}$ Para esta noticia, léase Josefo, AI 1.159.

${ }^{60}$ GE I 5.2. Véase Josefo, AI 1.159.

${ }^{61} \mathrm{El}$ «Índice» (2015) lo da como un autor distinto del ya referido.

${ }^{62}$ Así en el «Índice» (2015).
} 
nombra. Dicho Jerónimo es recogido después en las obras de Eusebio y Jorge Cedreno. Los estudiosos lo sitúan al final del periodo helenístico o comienzo del romano.

La $1^{\mathrm{a}}$ parte de la GE lo cita tres veces, por haber escrito sobre las antigüedades (sc. la historia antigua) de Fenicia; y asimismo por haberse ocupado del diluvio de Noé y del arca. Ya lo hemos visto: cf. apartado 2.2 (una vez) y 2.16 (dos veces).

\subsection{JubA (5).}

Dicho personaje (52 a. C.-23 d. C.) es nombrado por Plinio más de 60 veces en su Historia Natural. Realmente deberíamos citarlo como Juba II, rey de Mauritania entre los años 25 a.C. y el 23 d.C. Precisamente, su padre, Juba I, fue derrotado en Tapso (46 a.C.) por Julio César y se suicidó poco después. César recogió al niño, luego Juba II, el cual se crió y educó en Roma. Escribió numerosas obras en griego o latín sobre historia, historia natural, geografía, gramática, pintura y teatro, pero sólo nos han llegado algunos fragmentos. Monarca estudioso, organizó la primera expedición a las Islas Canarias a comienzos de la era cristiana. También se ocupó de diversos aspectos botánicos del monte Atlas.

En la primera parte de la GE tenemos cinco menciones de dicho rey de Mauritania $^{63}$. Precisamente, la obra alfonsí recoge un largo párrafo en que Plinio afirma que ese monarca habla del monte Atlas, localizado en Mauritania: se extiende en la explicación sobre el cocodrilo (llamado allí cocadriz, término que la Academia de la Lengua eliminó hace años del Diccionario por obsoleto) que vive en dicho país; explica que, para algunos, cuando llueve o nieva en el Atlas, crece o mengua el Nilo; se menciona también la fuente Nigris de Etiopía ${ }^{64}$. Además, a partir de otra cita, vemos que se habla de dos Mauritanias ${ }^{65}$, y de que Juba fue el primero que reinó sobre ambas. Resultó ser un buen rey que estudió la planta llamada euforbio, la cual, se nos dice, tiene un jugo blanco como la leche, y es buena para mantener la claridad de la vista, curar las mordeduras de serpientes y sacar la ponzoña que éstas hubieran inoculado en las personas mordidas ${ }^{66}$. Dicha planta fue usada por primera vez por un médico llamado Éuforbo (Eufarbio en GE), médico personal del monarca.

\footnotetext{
${ }^{63}$ Esa Mauritania ocupaba parte de los actuales Marruecos y Argelia. Fue anexionada por Roma y dividida en las provincias de Mauritania Tingitana y Mauritania Cesariense.

${ }^{64}$ GE I.5.7, Sobre este contenido, véase Plinio NH 5.51-54.

${ }^{65} G E$ I.10.29. En la secuencia leemos cuatro menciones de Juba.

${ }^{66}$ Véase Plinio, $N H$ 25.77-79.
} 


\subsection{Hestieo (1).}

Historiador del I d. C. En el texto estudiado de la GE, sólo lo leemos una vez, pero con la grafía deformada: Esto ${ }^{67}$. Pensemos que del Hestiâ̂os del griego, tenemos Hestiaeus, en latín. Ahora bien, hay muchas dudas sobre quién fue ese Hestieo, al que menciona Josefo (AI 1.107. Véase en nota a 2.2) como autor de una historia de Caldea. Los estudiosos lo sitúan al final del periodo helenístico o al comienzo del romano. También, en AI 1.119 (sólo esas dos referencias da el historiador judío). Posteriormente, Eusebio, Jorge Cedreno y Jorge Sincelo recogieron simplemente la primera cita de Josefo ya apuntada.

\subsection{8. $\operatorname{Moco}(1)$.}

Môchos sería la transcripción del antropónimo griego; Mochus es la apropiada en latín. En la GE, dentro de la parte estudiada, lo encontramos sólo una vez, donde se le llama Maço $^{68}$ (Cf. el ejemplo en 2.2). Según Josefo (AI 1.107), que lo cita sólo una vez, figura entre quienes escribieron una historia o relato sobre Caldea, sin dar ninguna indicación sobre la cronología.

\subsection{Josefo (743). Es el Autor ClÁSico MÁs CITAdO EN LA GE, PRIMERA PARTE ${ }^{69}$.}

2.29.1. Flavio Josefo (37-100 d. C.), nacido en Jerusalén, hijo de un matrimonio formado por un sacerdote y su esposa de sangre real, dio en seguida muestras de su aplicación e inteligencia. Visitó Roma en el año 64 y quedó impresionado por el poder romano. Intervino, como intérprete y mediador, al lado de Tito, hijo del emperador Vespasiano y posterior heredero del poder supremo, en la guerra declarada por Roma contra los judíos (conflicto relatado en su Historia de la guerra judaica contra los romanos, en siete libros, publicada en los años 75-79; en latín, Bellum Iudaicum=BI). El historiador viajó a Roma con los vencedores y ya vivió siempre allí gozando de los más altos honores otorgados por los sucesivos emperadores y teniendo a mano para su trabajo las inmensas bibliotecas imperiales. Para la GE, en la parte que nosotros estudiamos, la obra esencial de Josefo son las Antigüedadesjudias (=Antiquitates Iudaicae=AI), aparecidas en los años 93-94, en veinte libros. Abarca sucesos desde la creación del mundo hasta el año 66 y tiene como objetivo engrandecer al pueblo hebreo a los ojos del mundo

\footnotetext{
${ }^{67}$ Así en el «Índice» (2015).

${ }^{68}$ Tal consta en el «Índice» (2015).

${ }^{69}$ Para la presencia y utilización de Josefo en la GE, LidA DE MALKIEL(1959), MALKIEL (1968-1969), Rico (1972), EISENBERG (1973), FELDMAN (1984, con un apartado dedicado a la literatura española, pp. 865868), Perona (1989), Fraker (1996, pp. 177-190, ha señalado problemas de mala traducción del texto de Josefo en la obra alfonsí), Martin (2000), Avenoza (2003), Nieto IbáÑez (2004), Almeida-Trujillo (2008), Puerto Benito (2008), Almeida (2014), López FÉrez (2014), Bautista (2017), etc.
} 
grecorromano. Con respecto al texto bíblico, Josefo manejó tanto el hebreo-arameo como la versión griega de los Setenta, incorporando no pocos elementos de tradición oral (el nacimiento e infancia de Moisés; la campaña de éste contra los etíopes, etc.). El escritor menciona en ocasiones sus fuentes históricas: Beroso, Manetón, Nicolás de Damasco, etc. Aparte de su importancia esencial para la historia de los judíos, Josefo ha sido utilizado por numerosos estudiosos de la Biblia, tanto por las similitudes entre ambos conjuntos literarios como por las discrepancias respectivas. Muy leído desde la publicación de sus obras, la imprenta ayudó a la divulgación de las mismas en toda Europa, especialmente las traducciones latinas, entre las que sobresale la de 1481. Por su lado, la edición princeps del texto griego no vería la luz hasta $1544^{70}$.

Por mi parte, he contado 743 apariciones del antropónimo 'Josefo' en la parte estudiada de la GE.

2.29.2. Josefo fue traducido al latín relativamente pronto ${ }^{71}$. Posiblemente corresponde al círculo de Jerónimo la traducción de la BI atribuida a Pseudo Rufino de Aquilea (Tyrannius Rufinus Aquileiensis, cuya vida se fija en los años 345-411), bastante literal, realizada en el siglo IV, y que, hasta la fecha, no cuenta con una edición crítica. Posteriormente, Casiodoro encargó las versiones de AI y del Contra Apión, realizadas por sus colaboradores en el monasterio de Vivarium.

2.29.3. A la presencia e importancia de Josefo en la GE dedicó un excelente estudio Lida de Malkiel ${ }^{72}$. Resumo los puntos esenciales para mi objetivo.

2.29.3.1. La investigadora se detiene, en primer lugar, en la influencia de Josefo dentro de la literatura castellana desde el siglo XII y examina la GE como Biblia historial, pues la obra fue recogiendo noticias referentes a otros pueblos, siguiendo el método de Eusebio y Jerónimo, y, por eso, la GE gusta tanto de la Historia scholastica de Pedro Coméstor ${ }^{73}$.

2.29.3.2. La GE acude, en algún pasaje a Josefo porque éste «cuenta más», y se detiene en aspectos no tratados en la Biblia ni en otros comentaristas de la misma. Otro

\footnotetext{
${ }^{70}$ Son útiles las indicaciones ofrecidas en la bibliografía.

${ }^{71}$ Es muy conveniente consultar el The Latin Josephus Project.

${ }^{72}$ LIDA DE MALKIEL (1959; 1972). Importante es asimismo el trabajo de MALKIEL (1968-1969).

${ }^{73}$ La Historia Scholastica (recogida en la Patrología latina de Migne, v. 198, pp. 1053-1644) conoció un éxito inmediato y enorme desde su terminación hacia el 1170, cuando circulaban ya 25 manuscritos de la misma. De la obra se conocen al menos 800 manuscritos, de los que se hicieron miles de copias para uso de los estudiantes. La editio princeps apareció en Ausburgo, 1473.
} 
Algunas notas sobre la recepción de autores griegos o latinos en la General Estoria de Alfonso X [...]

asunto muy relevante es que Josefo juzgaba auténtica la tradición oral, incorporándola en su historia ${ }^{74}$.

2.29.3.3. Lida examina algún ejemplo de amplificación de la GE a la vista del relato bíblico y la explicación de Josefo: concretamente el asunto de cómo Esaú se casó con las dos mujeres cananeas. La estudiosa señala que es el plano didáctico, la enseñanza moral, lo que le interesa ante todo a Josefo y que, en ese punto, le sucede lo mismo a la GE.

2.29.3.4. Unas veces la $G E$ se empeña en poner de acuerdo a Josefo con la Biblia y con la Historia scholastica; otras veces, se aparta de la interpretación de Josefo, pues éste no recoge ciertos milagros que la GE sí ofrece; ésta, en ocasiones, acepta las interpretaciones racionalistas de Josefo, pero otras, no.

2.29.3.5. La GE sabe que al seguir a Josefo tenía a su lado toda la tradición historiográfica occidental, pero, no obstante, elige o amplía el relato mediante las obras arábigas y las de otros numerosos comentaristas.

2.29.3.6. La GE sigue la versión latina de las $A I$, la realizada quizá en el círculo de Jerónimo, pero atribuida al Pseudo-Rufino de Aquilea ${ }^{75}$.

2.29.3.7. Respecto a la comprobación de las fuentes, leemos en el texto alfonsí: «catamos nós el Josepho e fallamos que es assí» ${ }^{76}$. Ahora bien, los redactores no "cataron», ni se percataron del trueque que había hecho Rabano ${ }^{77}$ en su lectura de la Biblia, cuando, al tratar el origen de la sabiduría, puso Jubal en vez de Set, a quien se la había atribuido Josefo.

2.29.3.8. La GE tiene a Josefo casi por un santo, pues cabe deducirlo de frases alfonsíes como «Josefo e los otros sanctos padres» ${ }^{78}$.

2.29.4. Por mi lado destacaré algunos puntos que me han parecido dignos de señalar en la parte estudiada de la GE.

\footnotetext{
${ }^{74}$ LIDA (1959, p.168).

${ }^{75}$ LiDA (1959, p. 172) cree que se trata de la realizada por orden de Casiodoro en el siglo VI. La estudiosa revisa una serie de lugares donde la indicada versión latina ha dado lugar a confusiones tanto en la Historia scholastica como en la GE. Parte Lida de su propia versión de la traducción inglesa de Thackeray et alii (la edición bilingüe griego-inglesa de la Loeb), y de la edición del Pseudo-Rufino realizada por Girolamo Squarzafico, Venecia, 1486 (Véase Bibliografía).

${ }^{76}$ GE I.1.1.

${ }^{77}$ Puede acudirse a Rabano Mauro (Rabanus Maurus, Commentariorum In Genesim Libri Quatuor, en la Patrologia latina, vol. 107, col. 508. Con referencia a Jubal, leemos: De hoc Josephus historiographus Judaeorum ita refert: Jubal autem, inquit, musicam coluit et psalterim citharamque laudavit).
}

${ }^{78}$ GE I.11.50; I.17.2. 
2.29.4.1. Algunos asuntos los trata Josefo, pero no la Biblia, y llaman la atención en la GE. Así el interés de los hijos de Set por la astrología ${ }^{79}$ (Cf. AI 1.68-9).

2.29.4.2. A su vez, la GE se interesa, en ocasiones, por aspectos que no trata Josefo. Tal el asunto de los 37 hijos que Lamec tuvo con sus dos mujeres ${ }^{80}$.

2.29.4.3. Hay también asuntos que la GE adjudica a Josefo, pero que éste no dice o lo afirma de otra manera. Un ejemplo:

De los otros seis fijos de Jafet fallamos lo que avemos dicho, mas de Tubal nin Moisén nin Josefo non veemos que fablassen señaladamientre de puebla que él fiziesse nin los suyos, si non que Moisén llama su nombre Tubal, e que Josefo le dize Jobel, e más que él pobló los jebelos, e que los jebelos son los iberos, e iberos dizen en latín por españoles ${ }^{81}$.

En realidad, si lo traducimos, Josefo ${ }^{82}$ escribe (I.3.2) «Teobelo funda a los teobelos, que ahora se llaman iberos» (katoikízei dè kaì Theobélous Theóbēlos, hoítines en tô̂s nûn Íbēres ${ }^{83}$ kaloûntai). Pero, por si fuera poco, la GE añade, además, que ese nombre 'iberos' era del latín, equivalente a 'españoles', afirmación donde se contienen varios errores acumulativos.

2.29.4.4. Una constante de la GE es informar de cómo fue la transmisión de los saberes desde la Antigüedad, su paso por Grecia y Roma y luego entre «los latinos». Así, sin reparos cronológicos, la GE nos dice que Josefo afirma que los conocimientos del cuadrivio empezaron en Caldea ${ }^{84}$ y que Abrahán era entendido en el mismo ${ }^{85}$, como también lo fuera Tare (su padre) ${ }^{86}$, y cómo se apreciaron en Caldea los saberes de Abrahán ${ }^{87}$ y que los sabios caldeos elogiaron al citado ${ }^{88}$. Pues bien, si leemos a Josefo, resulta que éste no dice nada de los saberes de Taré, y, a propósito de Abrahán, indica que, precisamente, viviendo en Caldea, y por haber hablado en tales términos

\footnotetext{
${ }^{79} G E$ I.1.27. Es relevante el interés de la GE por el conocimiento de la astrología y los "estrelleros".

${ }^{80} G E$ I.1.14.

${ }^{81} G E$ I.3.1.

${ }^{82}$ AI 1.124-125.

${ }^{83}$ En realidad, esos iberos no son los de Iberia (luego, Hispania), sino un pueblo del Cáucaso.

${ }^{84} G E$ I.6.28.

${ }^{85}$ GE I.4.8.

${ }^{86}$ GE I.4.2.

${ }^{87}$ GE I.4.32.

${ }^{88}$ GE I.4.14.
} 
Algunas notas sobre la recepción de autores griegos o latinos en la General Estoria de Alfonso X [...]

de $\operatorname{Dios}^{89}$, se vio obligado a salir hacia Cananea, porque se habían levantado contra él los caldeos y los demás mesopotámicos ${ }^{90}$.

2.29.4.5. Nos detenemos en un asunto que la GE refiere que consta en Josefo, cuando o no figura en éste, o aparece pero de forma bastante distinta. Así, con respecto al nombre de Moisés:

E por aquel avenimiento que acaeciera assí a doña Termut quel fallara en el agua llamól Moisés, porque mois en el lenguage de Egipto, segund cuenta Josefo, tanto quiere dezir en el nuestro de Castiella como agua, e la es como librado. E ayuntó estas dos palabras de su lenguage mois e es e fizo d'ellas este nombre Moisés, que muestra segund esto tanto como librado de muert por agua, e aun librado dell agua o de la muert del agua ó pudiera morir e perderse si aquel acorro non fuesse ${ }^{91}$.

Josefo $^{92}$ nos dice escuetamente que (sc. la princesa) le puso el nombre en relación con lo sucedido por haber caído el niño en el río, pues «los egipcios llaman al agua môu, y esês, a los salvados» (Recordemos que el nominativo de Moisés en griego es Mōusês).

2.29.4.6. Recojo ahora un ejemplo de la llamada en retórica latina amplificatio, que, para muchos, comprende tanto la ampliación de lo tratado como la importancia que a dicho asunto se le otorga en el relato. Por ejemplo, el relato de la GE sobre las causas de la larga vida de los antiguos:

Cuenta Josefo sobr'esto en el quinto capítulo que cuando catáremos la vida de los omnes de agora e la vida de los antigos que non tengamos que yerro ninguno á ý en aver vevido tantos años los omnes del primero tiempo. Ca diz que los del primero tiempo muchas razones avién por que visquiessen tanto. Lo uno porque eran religiosos e fazién santa vida como fraires, e eran otrossí mas decerca de la fechura de Dios, e oyeran más palabras de las que Dios dixiera a sos padres e a sos parientes, e las aprendieran ellos e las tenién. Demás que non comién en aquel tiempo si non frutas e yervas, e pocas cosas otras. Mas que aun fasta'l diluvio nin comieran nunca carne nin bevieran vino, nin d'esto nin de ál cosa ninguna a demás por que de lieve enfermassen nunca, que por ello viniessen a muerte nin minguassen nada de su vida. Demás que razona Josefo que aquellos primeros omnes que eran más cerca Dios que se trabajavan de los fechos e de los saberes en que eran las virtudes de las cosas e los nobles e grandes pros, e que era esto el saber de la astrología e de la geometría e de todos los saberes liberales e de los otros. E que en escodriñar las virtudes d'esto que era tan alta cosa e tan noble e tan provechosa que por aduzirlos a las virtudes puras e ciertas que se non podrié fazer en menos de seiscientos años, e que tanto dura ell año grand. E que por estos bienes de que se trabajavan que les dio Nuestro Señor Dios tan luengas vidas en que lo pudiessen complir. E non solamente Moisén en la Biblia e los ebreos en su ebraigo, mas aun otros sabios muchos de otras

\footnotetext{
${ }^{89}$ AI 1.154-155.

${ }^{90}$ AI 1.157 .

${ }^{91}$ GE I.11.21-23.

${ }^{92}$ AI 2.228 .
} 
tierras e d'otras lenguas, e aun d'otras creencias fallamos que fablan en esta razón, e testiguan que fue assí. Esto tan bien en bárbaros como en griegos ${ }^{93}$.

En Josefo (AI 1.106-107) se nos dice, en resumen, que aquellos hombres eran amados por Dios y hechos por Dios mismo, y su alimento era apropiado para hacerles la vida más larga; eran hombres virtuosos, hacían buen uso de sus conocimientos geométricos y astronómicos y por eso pudieron predecir el curso de las estrellas, al haber vivido seiscientos años, que es lo que dura el año grande. Añade que se basa en los autores griegos y bárbaros que habían escrito sobre eso; ahora bien, nada dice respecto a que hubieran vivido como frailes, ni que comieran sólo yerbas y frutas, sin tomar carne y sin probar el vino.

2.29.4.7. Veamos ahora un error de bulto y una afirmación dudosa. En primer lugar, en torno a las causas de la torre de Babel, Josefo recoge el presagio de la 'Sibila' 94 , sin más explicaciones, pero en GE se habla de «Sevilla Cassandra» ${ }^{95}$.

Y una duda referente a la afirmación de la GE sobre que Josefo vio las dos tablas de la ley: «E cuenta Josefo que él las vío aquellas dos tablas en que Nuestro Señor Dios dio estos diez mandados de la ley a Moisén, e que assí eran escritos en ellas dedentro e defuera como vos contamos que dizen él e los ebreos ${ }^{96}$. No he encontrado confirmación a este aserto.

2.29.4.8. A un estudio estilístico correspondería el amontonamiento de menciones de Josefo, donde la GE busca posiblemente como apoyo la autoridad del historiador judío: a propósito de los hijos de Cam y Jafet; ${ }^{97}$ de que los hebreos se levantan contra Aarón y Moisés ${ }^{98}$; sobre las cubiertas del Tabernáculo ${ }^{99}$; sobre el duelo de los hebreos por la muerte de Moisés; de los años que vivió Moisés ${ }^{100}$; del casamiento de Abrahán

${ }^{93}$ GE I.2.13. Nótese la acumulación de autores. Además tres citas de Josefo. Advertimos importantes reflexiones sobre la comida y el vino. Advertimos, además, la idea sobre la existencia en época tan remota de la astrología y las artes liberales.

${ }^{94}$ AI 1.118. Es ésta la única vez en que el término 'Sibila' (en griego, transcrito, Síbylla) aparece en Josefo. La cita del historiador es recogida por Eusebio dos veces (Praeparatio evangelica 9.15.1; Onomasticon, p.40.16). Las palabras de la citada, en prosa, parecen ser una adaptación de unos versos recogidos en los Oráculos sibilinos (3.97-104).

${ }^{95}$ I.2.21-22. En la literatura griega es rara la asociación Sibila-Casandra: véase Suda, sigma 359. En la GE, dicho paralelismo puede haberse debido a la asociación de Casandra con la capacidad de profetizar.

${ }^{96}$ GE I.14.21-22.

${ }^{97}$ GE I.2.27-29. Diecisiete menciones.

${ }^{98}$ GE 1.23.13-16. Doce citas.

${ }^{99} G E$ I.16. 21-24. Doce referencias.

${ }^{100}$ GE I.29.22-24. Once citas. 
Algunas notas sobre la recepción de autores griegos o latinos en la General Estoria de Alfonso X [...]

con Cetura ${ }^{101}$, y sobre los hijos de Jafet ${ }^{102}$, donde afirma que los griegos cambiaron los nombres de distintos pueblos; de la adolescencia de José ${ }^{103}$; sobre que José dice ante sus hermanos quién es ${ }^{104}$; del enfrentamiento de Moisés y los suyos contra Sehón, rey de los amorreos ${ }^{105}$; de algunos adornos del Tabernáculo ${ }^{106}$; de las vestimentas hechas para Aarón y sus hijos ${ }^{107}$; sobre que los clérigos quedan librados del ejercicio de armas ${ }^{108}$; de los hijos de Esaú con sus tres mujeres ${ }^{109}$; de cuando Jacob iba a encontrarse de nuevo con su hermano Esaú ${ }^{110}$; de la primera salida de Egipto realizada por Moisés ${ }^{111}$; de los reyes que mandaban cuando Abrahán salió de Egipto ${ }^{112}$

\subsection{Claudio Ptolomeo (1).}

El prosista vivió entre los años 100-170 d. C. Ya lo hemos visto como Tolomeo en el apartado 2.1.2.

\subsection{ORÍGENES (52) $)^{113}$.}

2.31.1. Su vida se sitúa entre los años 185-254 d. C. Profesor de Teología en Alejandría dio conferencias por diversos lugares del imperio romano, especialmente en Cesarea Marítima, siendo muy apreciado por sus exegesis bíblicas. Considerado un padre de la Iglesia oriental y uno de los tres autores esenciales sobre la teología cristiana, le interesó a la GE por los numerosos escritos exegéticos dedicados a los cinco libros abarcados en la Primera parte de la obra que revisamos, a saber, sus Homiliae (al Génesis, Éxodo, Levítico), Commentarii (Génesis y fragmentos del correspondiente al Éxodo), Selecta y Adnotationes (ambos conjuntos con estudios especiales dedicados a cada uno de los cinco libros del Pentateuco). Sus obras, todas en griego, se perdieron o

\footnotetext{
${ }^{101}$ GE I.6.16. Once menciones.

${ }^{102}$ GE I.3.1. Nueve citas

${ }^{103}$ GE I.8.1. Nueve menciones.

${ }^{104}$ GE I.8. 21-23. Nueve citas.

${ }^{105}$ GE I.24.9-11. Ocho citas.

${ }^{106}$ GE I.15.56-58. Ocho alusiones.

${ }^{107} G E$ I.15.78. Siete citas. Con transcripción de nombres del caldeo, hebreo, griego y latín (en un caso se habla de «latin racional»).

${ }^{108}$ GE I.23.19-23. Siete citas en contextos próximos.

${ }^{109}$ GE I.7.44. Siete menciones.

${ }^{110}$ GE I.7.22. Seis citas.

${ }^{111}$ GE I.11.35. Seis citas.

${ }^{112}$ GE I.5.18-19 Seis menciones. Con una referencia histórica al emperador Teodosio.

113 En torno a su presencia en la GE, véanse Eisenberg (1973), López Férez (2014), etc.
} 
fueron mal transmitidas especialmente por el contenido heterodoxo de las mismas, lo que le acarreó numerosos problemas mientras vivió y dificultó la transmisión de sus escritos a la posteridad ${ }^{114}$. Buena parte de ellas nos han llegado en traducciones latinas de Jerónimo y Rufino.

2.31.2. En la primera parte de la GE he encontrado 52 menciones de su nombre. Se le cita sólo a él a propósito de sus comentarios sobre el Éxodo y Números. Con más frecuencia se le menciona junto a otros escritores y comentaristas.

\subsection{Eusebio de Cesarea (132) $)^{115}$.}

2.32.1. Su vida transcurrió, aproximadamente, entre el 260/265-339/340. Obispo de Cesarea Marítima (Palestina), fue exegeta e historiador de la cristianidad. De entre sus numerosas obras la más apreciada por la GE fue el Cronicón (en griego, transcrito, Chronicón), o la Crónica. El título griego era Pantodapè historía (Historia de todos los países), dividida en dos partes. El original de la primera se perdió, pero las tablas cronológicas de la segunda, Chronikoi kánones (Cánones cronológicos) fueron traducidas por Jerónimo al latín, constituyendo su Chronicon (Cronicón) ${ }^{116}$, continuación de la obra de Eusebio y punto de partida para numerosos anales realizados en la Edad Media.

En la primera parte de la GE he contado 132 menciones de Eusebio. Reparto lo esencial en tres apartados.

2.32.2. Alusiones sólo a Eusebio. En punto a la duración del reino de Asiria (I.3.26), la GE da la lista de los treinta y cinco reyes, desde Nino hasta Sardanápalo; I.3.28: Nino; I.4.19: la lista de los reyes diapolitas de Egipto; I.4.22: de los hijos de Semíramis, a la muerte de Nino; I.4.25: sobre las torres construidas por Semíramis; I.5.32: de la destrucción de Sodoma y Gomorra; I.6.17: en paralelo con los años de Abrahán, lo que sucedía en los reinos de Asiria, Sicíone y Creta; I.12.7: que Cécrope le puso nombre a Atenas.

2.32.3. Referencias a Eusebio-Jerónimo. I.4.1: en lo referente al comienzo de la tercera edad con la vida de Abrahán; I.4.29: la muerte de Semíramis, con tres citas del autor revisado; I.5.2: de la promesa de Dios a Abrahán, con dos citas del estudiado; I.6.18: apuntando al comienzo del reinado de los argivos, con dos citas de nuestro

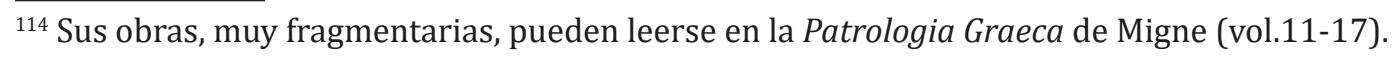

${ }^{115}$ Para su presencia en la GE, cf. Rico (1972, pp. 20-22), Eisenberg (1973), Casas Rigall (1999); Fernández Ordóñez (1999, pp. 113, 119-120), Almeida Cabrejas (2009), Salvo García (2009), López Fonseca-Ruiz Vila (2019), etc.

${ }^{116}$ Puede leerse, en latín e inglés, también en la red (http://www.tertullian.org/fathers/jerome chronicle 00 eintro.htm). La cito simplemente por página.
} 
autor; I.7.5: respecto al ajuste de la cronología histórica a los años de Jacob; I.7.7: en lo referente a los reyes pastores de Egipto; I.7.14: ajuste de Ínaco y Foroneo, reyes sucesivos de Argos, a los años de Jacob; I.7.27: sobre Apis, rey de Argos, con la explicación de que pasó a Egipto y se casó con Isis; I.8.8: cuando José fue encarcelado tras lo ocurrido con la mujer de Putifar, quiénes eran los reyes en los otros países del mundo; I.9.13: sobre los faraones Nicrao ${ }^{117}$ yAmosis ${ }^{118}$ y el poder de José; I.9.45: acerca de los saberes de Prometeo, cuando José ya llevaba 52 años en el poder; I.10.5: qué reyes había en los demás países del mundo a la muerte de José; I.10.8: respecto a los años que Jacob vivió en casa de José, en Egipto; I.10.9: respecto a los 214 años que duró la servidumbre de los hebreos en Egipto; I.10.13: en punto a los 74 años desde la muerte de José hasta el nacimiento de Moisés y el silencio de la Biblia sobre los mismos; I.10.39: acerca de los curetes y coribantes y cómo poblaron Cnoso; I.10.41: de los faraones Achor y Cencres ${ }^{119}$, así como el rey Cécrope de Atenas; I.11.30: Amram, padre de Moisés, cumplió 70 años cuando éste nació; I.11.31-32: respecto al faraón Horo y de los reyes coetáneos en otros países. Mención del primer Hércules, el que pasó de Grecia a África; I.11.33-34: sobre los cuatro Hércules que hubo y sus épocas. Contamos cinco menciones tanto de Eusebio como de Jerónimo; I.11.49: a propósito de los 40 reyes de Atenas; I.11.54: Moisés, a los 42 años, se retiró al desierto para filosofar; I.12.5: de los faraones Cencres (que murió en el mar cuando perseguía a los hebreos en su salida de Egipto) y Acherres; I.13.1617: acerca del faraón Cencres y los reyes coetáneos en otros países, como Erisictonio, rey de Atenas, y, además, Hércules 'Desanao' ${ }^{120}$, «el sabio». Leemos una etimología atrevida: «fue dado en Grecia un logar pora oír todos los pleitos e librarlos, e a aquel logar establecido pora aquesto pusiéronle nombre Ariópago; e lieva este nombre de ares, que dizen los griegos por lo que nós en el lenguage de Castiella dezimos virtud o virtudes»; I.14.prólogo y 1: los nombres de los faraones, Cencres, el que persiguió a

\footnotetext{
${ }^{117}$ Según la GE I.8.5 es el nombre de Amosis en egipcio. El citado faraón hizo muchas conquistas, y llegó incluso a España y luchó contra «el rey Rodrigo el menor»: GE I.8.5. En los años de Nicrao tuvieron lugar los sucesos principales de José: la venta, lo ocurrido con la mujer de Putifar, el alto cargo ocupado en el reino, etc. El hijo y sucesor de aquél se llamó Amosis: GE I.9.13.

${ }^{118}$ Figura como Amasis, en Jerónimo (pp. 42-43).

${ }^{119}$ Constan, respectivamente, como Athoris y Chenchres en Jerónimo (pp. 60-61).

${ }^{120}$ Mencionado seis veces en la parte que hemos revisado. Cf. Jerónimo (pp.62-63): Hercules cognomento Desinaus in Phoenice clarus habetur: unde ad nostram usque memoriam Cappadocibus et Heliensibus Desinaus adhuc dicitur. Puede traducirse así: «Hércules, con la denominación Desinao, es considerado famoso en Fenicia. Y, por eso, hasta nuestra memoria, es llamado Desinao todavía por los capadocios y eleos». El sobrenombre Desinaus ha suscitado muchas variantes en la tradición exegética: se le ha leído como Desanaus, Doseneus, Desonaus, etc. Puede ayudar a entenderlo lo que tenemos en Jorge Sincelo, Ecloga chronographica, p. 180.6. Una traducción sería: «Afirman algunos que Heracles es conocido en Fenicia, llamándosele Disandán, como así es denominado hasta ahora por los capadocios y eleos». Podría tratarse de una cita tomada del Cronicón de Eusebio, autor al que Sincelo cita 141 veces en su Ecloga, y al que menciona tres líneas más arriba del texto traducido. Hay otro problema, no menor: Disandán es un hápax en la literatura griega, según el $T L G$ en línea.
} 
Moisés y murió por tal causa, y Acherres ${ }^{121}$, su sucesor. Asimismo, cómo se llamaban en las historias de Egipto; I.25.24: que a los 25 años del caudillaje de Moisés, Esténelo, buen rey, mandaba en Argos, y durante su reinado le llegó Dánao «pobre e lazrado, e fuyendo»; I.25.26: que Dánao y Egipto ('Egisto' en la GE) tuvieron respectivamente cincuenta hijas y cincuenta hijos, y vivían «en Assiria ant'el rey Nino, su hermano» ${ }^{122}$, pero no cabían allí tantos y decidieron irse a Grecia. Y, según Eusebio y Jerónimo «que non es de maravillar, e mayormientre entre las yentes bárbaras ó ellos eran e fizieron aquellos fijos, ca diz que podrié allí aver cadaún varón mugieres amigas cuantas quisiesse no hay que extrañarse de tantos hijos e hijas».

2.32.4. Alusiones a Eusebio con referencias expresas al nombre de otro u otros comentaristas: I.3.25: con respecto a los saberes de los de Babilonia, se recurre al Panteón (de Godofredo de Viterbo), «Eusebio en su Crónica» y Cicerón al comienzo de su primera Retórica; I.3.30: sobre los cuatro reinos principales del mundo. Junto a Orosio y Coméstor; I.3.31: acerca del reino de Sicíone, con ocho citas de Eusebio en poquísimo espacio, y, además, Jerónimo y Coméstor; I.4.21: que Nino venció a Zoroastro. Junto a Godofredo; I.4.30: del reinado de Cres en Creta y otros asuntos de esta isla, con tres citas, junto a Godofredo; I.5.25: sobre la llegada de los hebreos a la tierra prometida, «assí como cuenta Eusebio e otros muchos»; I.6.16: en torno a Abrahán y sus hijos, «como las dizen Eusebio e maestre Pedro e otros»; I.6.28: sobre Ío, Ínaco y su paso del Bósforo, con una etimología no muy desacertada («Ínaco, el río de la cibdad de Argos de Grecia es llamado Bosfor de Ío su fija del rey, e compusieron este nombre Bosfor de bos, que dezimos los latinos por vaca e por buey, e foros que dize el griego por levar, porque aquel río e aquella mar levaron e passaron a Ío de Grecia a Egipto. E es Bosforo cosa de que fabla el Plinio e otros muchos sabios»). Con alusión a Plinio, dos citas del autor revisado, Jerónimo y Lucas (sc. de Tuy; el Tudense); I.6.32: a propósito de la muerte de Abrahán. Con presencia de Josefo y Jerónimo; I.6.33: de la muerte de Ismael. Con el apoyo de Jerónimo, Coméstor y «la estoria de Egipto»; I.7.17: con referencia a los años de Jacob, un levantamiento contra Foroneo. Con la presencia de Jerónimo y Orosio; I.7.24: en lo relativo al rey Ogiges y el nacimiento de Palas («e los griegos llámanla Minerva» $)^{123}$. Se recurre a Jerónimo y Lucas de Tuy; I.7.30: respecto a los años que vivió Isaac. Con apoyo de Josefo y Jerónimo; I.7.42: a propósito de la Edad de oro, con

\footnotetext{
${ }^{121}$ Figura, tal cual, en JERónimo (pp. 62-63).

${ }^{122}$ En JeRónimo (pp.16-17) leemos que Nino, hijo de Belo, fue el primero en reinar sobre toda Asia, excepto India, durante 52 años. Según el escolio a Esquilo, Pr. 773-4, de Î́o (la hija de Ínaco, amada por Zeus), nació Épafo; de éste, Libia; de ésta, Belo; de éste, Dánao. Para muchos, hijos de Libia fueron Agenor y Belo; hijos de éste fueron Egipto y Dánao. Pero contamos con otras versiones, menos corrientes. Así, Tzetzes, Chiliades (7.116) dice que «hijos de Belo fueron Nino, Agenor, Fénix, Egipto, Dánao y Fineo».
}

${ }^{123}$ Nótese el error, pues los griegos la llamaban 'Atenea', teónimo que no aparece en la parte de la GE revisada. 
recurso a Cicerón, Ovidio, Jerónimo y las «estorias de Rocas» ${ }^{124}$; I.7.43: sobre la unión de Júpiter ${ }^{125}$ y Níobe, padres de Dárdano y Tros. Al lado de Jerónimo y Godofredo; I.8.5: que cuando José fue vendido, reinaba en Egipto el diapolita Amosis. Se apoya en Orosio, Segeberto de Gembloux y Godofredo; I.9.16: respecto a quiénes eran los reyes en los países del mundo cuando José tenía, respectivamente, 50 y 20 años. Apoyado en Jerónimo y Ovidio; I.9.42: con referencia a Deméter y las medidas de las mieses, vino y aceite, así como los reyes de los países del mundo. Se apoya en Jerónimo y Godofredo; I.10.10: otras cuentas de los años de servidumbre de los hebreos en Egipto, con las discrepancias entre Josefo (400 años) y Eusebio-Jerónimo (430). Con alusión a Josefo, al autor estudiado (con tres citas), Jerónimo y Lucas de Tuy; I.10.16-17: sobre los faraones «e esto ál dizen Eusebio e Jerónimo, que son santos e sabios de creer; el segundo faraón, segund Eusebio e Jerónimo otrossí, fue Chebrón; el tercero Amenofes; el cuarto Mefres; el quinto este Misfarmotosis ${ }^{126}{ }$. Cita también la Historia de Egipto ${ }^{127}$, como discrepante; también a Coméstor, tocante al último faraón mencionado; I.10.21: a propósito del monte Atlas (cf. nuestro apartado 2.6, referido a Eurípides); I.10.30: respecto a los reyes coetáneos de Atlas como rey del Algarbe de España y de África, según Eusebio «e Lucas en el Libro de la estoria de Troya»128; I.10.33: que Moisés nació en los años del faraón Amenofes, hijo del faraón Tamoso ${ }^{129}$. Se apoya en Eusebio, Jerónimo, Lucas de Tuy, Coméstor y Godofredo; I.10.34-37: incide en Tamoso y de los reyes coetáneos en otros países. Recurre a Eusebio (cinco citas), Jerónimo y Godofredo. «E assí como cuentan las crónicas de Eusebio e de Jerónimo, aquellos cuatro reyes faraones que regnaron en Egipto en aquel tiempo que dezimos fueron éstos por sus nombres segund la fabla egipciana: el primero Mefres, en cuyo regnado finó Josep tres años por andar d'él; el segundo Misfarmotosis, que regnó XXVI años; el tercero Tamoso, IX años; el cuarto d'ellos fue Amenofes»; I.11.3: una discusión sobre el faraón Amenofes, según los distintos autores. Recurre a Eusebio (dos citas), Jerónimo, Lucas de Tuy, Coméstor y Godofredo; I.12.7: respecto a lo sucedido cuando Moisés regresó a Egipto, y, además, los hechos del rey Cécrope de Atenas, procedente de Egipto. Con

124 Sobre este curioso personaje, tenido por hijo de un rey, procedente de India y que anduvo por el mundo buscando los saberes, y resultaría ser el fundador de Roma, según noticias sacadas de una fuente desconocida, quizá árabe, véase Fernández-Ordóñez (1992, p. 94).

${ }^{125}$ Leemos así: «ca este rey Júpiter fallamos que fue el rey d'este mundo fasta'l día d'oy que más fijos e más fijas ovo, e condes de muy grand guisa todos los más, e reínas».

${ }^{126}$ En JERónimo (pp. 44-49) constan, respectivamente, como Chebron, Amenophis, Mephres y Mispharmuthosis. En Teófilo, Ad Autolyc. 3.19 leemos que el faraón que expulsó a los hebreos fue Téthmôsis. Y sus sucesores fueron Chebrôn, Aménōphis, la hermana de éste Améssē, Mếphrēs y Mēphramoúthōsis.

${ }^{127}$ La obra de Alguazif, sabio egipcio, se titula Estoria(s) de Egipto. Es fuente esencial para los faraones y la historia de Egipto. Cf. FERNÁNDEZ-ORDóñEZ (1992, pp. 180-181).

${ }^{128}$ Una obra de Lucas de Tuy que no nos ha llegado.

${ }^{129}$ En la parte estudiada de la $G E$ aparece como Tamos (cf., por ejemplo, GE I.10.18) o Tamoso. Era hijo de Misfarmotosis (GE I.4.19; I.10.32; etc.). Para la lista de los 36 faraones diapolitas, cf. GE I.4.19. 
alusión a Eusebio, Jerónimo y Lucas de Tuy; I.12.8: de lo que Moisés habló con el faraón Cencres. Se mencionan Eusebio, Jerónimo y Josefo; I.12.31: Eusebio, Jerónimo y los relatos arábigos: «E dize un sabio de los arávigos que ovo nombre Alguazif, e escrivió las estorias de Egipto, que a este Faraón en cuyo tiempo esto conteció e que iva empós los ebreos quel llamavan Talme en arávigo, e en ebraigo Talmai, e los egipcianos, segund cuentan Eusebio e Jerónimo, le dizién Cencres, como vos avemos nós ya dicho. E avié una fija quel dizién Munene; e este nombre Munene quiere dezir en arávigo tanto como en el nuestro lenguage de Castiella lo que desseamos»; I.13.6: que el faraón de Moisés y el de José son distintos. Se acude a Eusebio y Jerónimo contra ciertas fuentes arábigas; I.13.14: sobre el incendio de Etiopía por causa de Faetón, y cuándo sucedió. Fuentes son Platón, Orosio, Eusebio y Jerónimo; I.13.15: sobre incendios, terremotos y pestilencia en otros lugares, aparte de Egipto. Se menciona a Platón, Eusebio, Jerónimo, Orosio y Lucas de Tuy; I.14.16: en torno a quiénes eran los sacerdotes. Aparte de Eusebio y Jerónimo, se acude a Coméstor; I.14.36: sobre las discordancias de los nombres en Eusebio y Jerónimo ( $\mathrm{E}$ fallamos muy grand desviamiento en los nombres de los faraones que esta estoria de Egipto pone de los que leemos que ponen en sus crónicas Eusebio en el griego e Jerónimo en el latín») y en los autores arábigos. Recurre, además, a «Precián en el su Libro mayor» ${ }^{130}$; I.21.3: cronología del mando de Moisés en paralelo con los reyes de otros países, a propósito de Arcas, rey de Arcadia, hijo de Júpiter y Calisto. En apoyo, además de Eusebio y Jerónimo, se acude a Ovidio; I.21.29: sobre que Perseo, rey de grandes hechos, sería coetáneo de los años de Moisés cuando estaba con los ganados de Jetro. Además de Eusebio y Jerónimo, la GE se apoya en el Panteón de Godofredo; I.22.11: el año en que Moisés partió del Sinaí hacia Canaán se pone como clave para la cronología universal y la de los reyes de otros países. En Egipto reinaba el faraón Acherres, según Eusebio y Jerónimo, pero la reina Doluca ${ }^{131}$, de acuerdo con la «Estoria de Egipto»; I.23.26: al faraón llamado Cencres en Eusebio y Jerónimo, la mencionada Historia de Egipto lo denomina Talme, y a su muerte sucedió lo de la reina Doluca, que «endereçó su regno»; I.29.22: que Moisés vivió 120 años. Se acude a Josefo, Eusebio, Jerónimo y Coméstor.

\section{Autores de literatura latina}

Hemos revisado dentro de la GE (Primera parte) la recepción de autores latinos desde el siglo III a. C. (periodo republicano) hasta mediados del V d. C. (periodo postclásico). Nuestro estudio deja pues abierta la investigación para la presencia en la

\footnotetext{
${ }^{130}$ A saber, Prisciano (500-530 aprox.) y sus Institutiones Grammaticae.

${ }^{131}$ El nombre parece proceder de Les Prairies d'Or, traducción francesa del tratado escrito en el siglo X por Al-Masudi, especialista en el género geográfico-enciclopédico dentro del mundo musulmán.
} 
obra alfonsí de escritores en latín correspondientes al periodo medieval (siglo VI-hasta el XIII, es decir, los años de la redacción de la GE).

\subsection{VARRÓN (6).}

Su vida transcurrió entre los años 116-27 a. C. Plinio lo menciona en numerosas ocasiones (142 citas). Casi todas las apariciones de dicho autor en la parte de la GE estudiada corresponden, en realidad, a alusiones procedentes de la Naturalis Historia, la cual tuvo importancia relevante en el texto alfonsino. Veamos algunas citas. Así, sobre la fundación de una ciudad en el Capitolio romano a manos de un hijo de Hércules ${ }^{132}$; acerca de los nombres del Tíber: «Vino aquel rey Itallo e lidió allí con este rey Tibre, e mató Italo a Tibre en la fazienda en aquel río. E d'aquí dizen Virgilio e Varro que ovo este río Albula de Roma este nombre Tibre d'aquel rey Tibre que murió en él»»133. A propósito de las serpientes venenosas: «E dize otro sabio que llamaron Varro que del linage d'estos omnes á ý aún, mas son pocos, e aun diz que éstos con la saliva sola sanan los feridos de las serpientes; tal natura an contra ellas» ${ }^{134}$. Después, encontramos un elogio de asno, animal muy útil y muy sufridor de muchas dificultades, menos el frío ${ }^{135}$. Con referencia a las clases de lana y del arte de tejer con ella, la GE acude a Plinio y menciona cómo Varrón habla de una toga de lana hecha por la reina Tanaquil, luego llamada Gaia Cecilia, y cómo Servio Tulio, rey de Roma, la llevó puesta y que después la citada prenda quedó expuesta en el templo de la Fortuna ('Aventura', en el texto alfonsí) $)^{136}$.

\subsection{Cicerón (8). En la GE, primera parte, siempre llamado Tullio ${ }^{137}$.}

Vivió entre los años 106-43 a. C. Realmente la GE, en la sección aquí revisada, lo cita exclusivamente a propósito de las costumbres de los primeros hombres:

Pues salvo ende estos de la liña e pocos otros todos eran de comienço tales como avemos dicho, e bivién más a maneras de costumbres de bestias que non de omnes, assí como cuenta Tullio en la su primera Rectórica, e otorgan con él muchos otros sabios. Ca luego que avién fambre e sed comién e bevién cada que les tomava ende sabor, como fazen

\footnotetext{
${ }^{132}$ GE I.3.22. No he localizado la procedencia de la cita sobre Varrón.

${ }^{133}$ GE I.3.22. Plinio, NH 3.53 menciona ese cambio de nombre.

${ }^{134}$ GE I.8.15. Se basa en Plinio, $H H$ 7.12.

${ }^{135}$ Según el naturalista, por esa razón, dicho animal no se cría en el Ponto. En Alfonso, en cambio, se nos dice que «por esto non á asnos en Escocia nin en ninguna otra tierra que sea muy fría como aquélla».

${ }^{136}$ GE I.20.28, con dos citas del autor revisado. El texto procede de NH 8.194.

${ }^{137}$ Para algunos aspectos de la presencia del orador y retórico en Alfonso X y en la GE, cf. EISENBERG (1973), Díez de Revenga (1988), Montoya Martínez (1995), Fraker (2006), etc.
} 
agora e fizieron siempre las otras animalias, que nin entienden nin an razón de se guardar ende $^{138}$.

Esta afirmación la leemos en otros contextos ${ }^{139}$.

\subsection{VirgiLIO (5) ${ }^{140}$.}

Se le fecha entre los años 70-19 a. C. Lo hemos visto ya en el apartado 2.6, a propósito de Atlas. También en 3.1, respecto al nombre antiguo del Tíber. Veamos, pues, los otros lugares. Así, hablando de los primeros hombres: «E salieron de las choças, e moravan en tiendas que levavan de logar en logar con sos ganados. E a estas tiendas dize en latín magalia, e es magale casa pastoril fascas de pastor, assí como diz Virgilio en el libro a que dizen Bucólica, ó fabla él de los pastos e de los ganados» ${ }^{141}$. Con respecto al trípode, que se pone en relación con la bíblica Rebeca, cuando ésta se puso el laurel bajo la cabeza:

que se puso allí so la cabeça a aquella manera del árvol laurero a que los gentiles llamavan tripoda, e era estonces tripoda, assí como fallamos en los autores de los gentiles Virgilio, Ovidio, Oracio e otros, una mesa de tres pies sobre que ell ídolo del Sol e de Júpiter, que eran los mayores dioses que ellos avién, davan las sus más ciertas respuestas a sos romeros e a los pueblos que les vinién a demandar sus dubdas que les acaecién ${ }^{142}$.

También en lo referente a los caballos: «Cuáles cavallos e de cuáles fechuras se deven escoger por mejores Virgilio lo muestra, e cuéntalo otrossí Plinio en el libro de la lid de los cavalleros ${ }^{143}$, e vemos que muchos son los sabidores que los conocen bien ${ }^{144}$.

\subsection{Horacio (3) ${ }^{145}$.}

Vivió entre el 65 y el 8 a. C. Lo hemos encontrado ya dos veces: en los apartados 2.6 y 3.3. Un tercer testimonio hace referencia al río Ladón:

\footnotetext{
${ }^{138}$ GE I.3.10. El pasaje corresponde a Cicerón, De inventione 1.1.2-3.

${ }^{139} G E$ I.3.25, con dos citas del autor romano. Cicerón, contra lo que pudiera deducirse del texto alfonsí, no menciona nunca a Nino.

${ }^{140}$ En torno a la presencia de Virgilio en las obras históricas de Alfonso X, cf. Rico (1972, pp. 170-174), DíEZ de Revenga (1988), CASAs Rigall (1999, pp. 19, 109, 239), Bizarri (2019, pp. 77-78), etc.

${ }^{141} G E$ I.3.12. En Virgilio figura magalia en dos ocasiones. Se trata de la Eneida, 1.421; 4.259, pasajes bien comentados por Servio. No consta, en cambio, en las Bucólicas.

${ }^{142}$ GE I.7.2. Efectivamente, tripus, -odis, aparece, entre otros lugares, en Virgilio, Eneida 3.360, 5.510, 9.265; Horacio, Carmina 4.8.3; Ovidio. Her. 3.32, Fast. 3.855, Ars 3.789.

${ }^{143}$ La obra alfonsí se apoya en $N H$ 8.162: forma equorum, quales maxime legi oporteat, pulcherrime quidem Vergilio vate absoluta est; sed et nos diximus in libro de iaculatione equestri condito, et fere inter omnes constare video. Efectivamente, entre las obras perdidas de Plinio, figuraba un De jaculatione equestri (es decir, sobre el lanzamiento de la jabalina estando montado a caballo).

${ }^{144}$ GE I.20.22.

${ }^{145}$ Para la presencia del autor en las obras históricas de Alfonso X, véanse Rico (1972, p. 163), DíEz DE
} 
E diz que este río Ladón corre por medio de Grecia, e que es río de muy buena agua muy clara e muy sana, e á muchas cañaveras por todas las riberas d'él, e allí a aquella ribera muestra que vinieron todos los filósofos de Grecia a estudiar sobre las siete artes liberales. E, assí como dize Oracio e las glosas de sobr'él comién allí los filósofos muy poco pan, e de las raízes de las yervas que fallavan por ý, e bevién del agua d'aquel río, e allí estidieron fasta que apuraron aquellos siete saberes e los pusieron a cadaúnos en sus reglas ciertas ${ }^{146}$.

\subsection{Ovidio $(76)^{147}$.}

Su vida se sitúa entre los años 43 a.C.-17 d.C. Lo hemos visto ya en el apartado 2.32 .4 (2 veces). Conviene decir algo sobre la importancia de dicho poeta en la GE ${ }^{148}$, pues en ella se traducen al castellano las Heroidas ${ }^{149}$, se vierten pasajes selectos de las Metamorfosis (llamado «el Libro Mayor», en Alfonso; o, también, «el Ovidio Mayor») y se utilizan con frecuencia los numerosos tratados exegéticos medievales dedicados especialmente a esta última obra ovidiana. Recogeré ahora lo esencial de las secuencias alfonsíes siguiendo el mismo orden de la obra estudiada. Así, pues, el poeta latino es mencionado a propósito de los Gigantes ${ }^{150}$, la Torre de Babel, los Gigantes (de nuevo) y su intento de poner el monte Pelión sobre el Osa, Tifoeo, los planetas y la metamorfosis de los dioses, donde se enlaza la referencia a la reina Semíramis, en punto a los muros que mandó hacer con ladrillos de tierra, con el relato de lo ocurrido a Píramo y Tisbe ${ }^{151}$; al hablar del rey Ínaco de Argos, la GE se ocupa del río llamado como ese monarca, y, en especial, de Ío, la hija del mismo, y del enamoramiento de Júpiter y cómo logró unirse con ella, y cómo Juno lo advirtió, siendo Ío tranformada en vaca, y cómo la reconoció su padre por las letras que con la pezuña hizo en tierra, y cómo Juno dispuso que Argos la vigilara con sus cien ojos, y la muerte de éste a manos de Mercurio por orden

\section{REVENGA (1988).}

${ }^{146}$ GE I.6.28. No he hallado fuentes clásicas que avalen lo afirmado en la Estoria. El río Ladón (en latín Ladon, -nis) aparece, en cambio, en varios autores de la época clásica romana: Ovidio, Plinio, Séneca, etc.

${ }^{147}$ Son numerosos los estudios sobre la presencia e influencia de Ovidio en la GE. Recojo sólo los más relevantes: SolaLINDE, 1915; 1928; 1934; 1936; LIDA DE MALKIEL, 1958; 1959; GINZLER, 1971; RICO, 1972; EISenberG, 1973; ImPey, 1980; Coulson-Roy, 2000; Cuesta Torre, 2007; Cristóbal, 2011; López Férez, 2011; 2015; Ekman, 2013, SAlvo García, 2010a, 2010c, 2012, 2014.

${ }^{148}$ En la parte estudiada, son las Metamorfosis (así se la denomina en una ocasión: GE I.7.42) y las Heroidas las dos obras ovidianas más mencionadas, especialmente la primera. Otros escritos aludidos son Fastos (o Faustos, o Libro de los fastos) y Remedios de amor (GE I.21.16: «E Ovidio otrossí en el libro de las sanidades dell amor a que llaman Ovidio De remedio amor»),

${ }^{149}$ «El Libro de las Dueñas», o «Epístolas de las Dueñas», en la GE.

${ }^{150}$ GE I.2.21. Véase, Ovidio, Met. 1.150-160.

${ }^{151}$ GE I.4.27, con dos citas del poeta. Precisemos que el amor de Píramo y Tisbe en Babilonia, el primero de seres humanos dentro de las Metamorfosis, está rodeado de una atmósfera oriental: Met. 4.55-166. Los enamorados vivían en moradas contiguas, y es esencial la grieta que Píramo hizo en el muro para hablar con su amada. La GE recoge en latín los primeros cuatro versos (Met.4.55-58, donde se insiste en la extraordinaria belleza del joven y en la distinción de la doncella entre todas las de Oriente). 
de Júpiter, y cómo Ío llegó a Egipto donde fue considerada diosa; ${ }^{152}$ en lo tocante al nombre de 'Atenas' leemos ${ }^{153}$ : «E por esso diz Ovidio en el su Libro mayor que Atenas quier dezir tanto como logar sin muert...»; en relación a la primera edad del mundo, se nos dice: «que de las seis edades que dixiemos del tiempo que la primera tal era como oro» ${ }^{154}$; asimismo, la GE revisa otras uniones del dios supremo: «Otrossí Júpiter en Ceres ovo a Proserpina, assí como diz Ovidio en el libro de Fastos e en ell Ovidio mayor e en otros logares, e acuerdan con él otros sabios que fablan d'esta razón» ${ }^{155} ;$ y, apuntando a Dárdano, leemos: «Onde cuenta Ovidio en el Libro de Faustos [...] que ¿quién dubdará de Dárdano que non es fijo de Júpiter e de Electra?» ${ }^{156}$; dentro del mismo pasaje la GE alude a Atlas: «que fizo fazer un grand árvol como maçano con sus fojas e con sus frutas como maçanas todo d'oro» ${ }^{157}$; además, se hace referencia a la lucha de Hércules contra Anteo, con las palabras del primero: «Mas dixol Hércules, segund cuenta Ovidio: 'Non assí, Anteo, non assí, mas cadrás acá e non a tierra'. E allíl tovo suso fasta que se otorgó Anteo por vençudo, e estonces le dexó Hércules» ${ }^{158}$; por su lado, tras haber relatado el diluvio de Deucalión y el incendio causado por Faetón, la GE, contraponiendo 'historia' /'poesía', expone lo siguiente:

Del fecho d'este diluvio e d'esta quema vos contáramos otras razones que á ý muchas d'ellas, mas dexámoslas por esta razón, e contar vos iemos ende más razones que á ý en el fecho d'este diluvio e d'esta quema, mas dexámoslas por esta razón: los autores de los gentiles, que fueron poetas, dixieron muchas razones en que desviaron de estorias; e poetas dizen en el latín por aquello que dezimos nós en castellano enfeñidores e assacadores de nuevas razones, e fueron trobadores que trobaron en el latín, e fizieron ende sos libros en que pusieron razones estrañas e maravillosas e de solaz, mas non que acuerden con estoria menos de allegorías e de otros esponimientos; e assí fizo Ovidio, que fue poeta, en las razones d'aquel diluvio e d'aquella quema, de que dize él más que otro sabio e eñadió ý unos mudamientos d'unas cosas en otras que non son estoria por

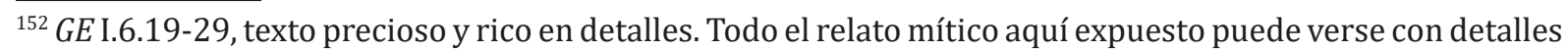
en Met. 1.567-746. Algunas manifestaciones de la GE nos llaman la atención. Por ejemplo I.6.26: «E el Ovidio Mayor non es ál entr'ellos si non la teología e la Biblia d'ello entre los gentiles».

${ }^{153}$ GE I.7.40. No he hallado en Ovidio confirmación al aserto de este pasaje alfonsí, según el cual se habría establecido un cierto paralelismo entre Athênai, el nombre de la ciudad, y athánatos, 'inmortal'. Sí, en cambio en los Integumenta Ovidii de Juan de Garlandia (6.vv. 279-280): Athanatos grecum sonat inmortalis, Athenas / Nominat hinc Pallas famaque vivit adhuc.

${ }^{154}$ GE 1.7.42, donde se menciona cuatro veces al poeta latino. En Met. 1.89-150 se nos habla de las cuatro edades: oro-plata-bronce-hierro.

${ }^{155}$ GE I.8.2, en un extenso pasaje, donde se expone también el rapto de Prosérpina por Plutón, con muchos detalles sobre Sicilia ('Cecilia' en la $G E$ ); se recurre tres veces al latino. Véanse en Ovidio, Fasti 4.587 y Met.5.341-661.

${ }^{156}$ GE I.10.31. Véase, Ovidio, Fast. 4.31.

157 Ovidio, Met. 4.646-648.

158 GE I.11.32, con dos alusiones al latino. Véanse en Ovidio, Met. 9.183-184; Heroidas 9.70-72, con indicaciones sobre el enfrentamiento. No obstante las palabras alfonsíes parecen corresponder a Lucano, Bellum civile 4.648-651.
} 
ninguna guisa. E dexámoslas aquí por ende; e esto que aquí avemos ende dicho cumpla porque aquesto es estoria ${ }^{159}$.

Siguiendo con nuestra búsqueda, la historia alfonsí recurre a Ovidio en busca de autoridad para un vocablo de la traducción de Jerónimo, el crabro ${ }^{160}$, es decir, el 'tábano', o 'avispón'161; y, a propósito del cielo claro y limpio, se cita al poeta latino ${ }^{162}$; asimismo, para los cuatro elementos, la GE recurre a Ovidio:

Onde dize Ovidio en el comienço del primero de los XV libros del su Libro mayor estos cuatro viessos por este latín: Non regio foret ulla seis animalibus orba, Astra tenent celeste solum formeque deorum, Cesserunt nitidis habitande piscibus unde, Terra feras cepit, volucres agitabilis aer.[...] E segund estas palabras de Ovidio, que fue varón tan sabio e uno de los tribunos de Roma, que era grand principado, e que dixo tantas buenas palabras e de grand saber, las creaturas del cuarto elemento, que es el fuego, que son, como oyestes, las estrellas e las formas de los dioses, animalias son ${ }^{163}$.

Con referencia al mítico Arcas, la GE alude a Eusebio y Jerónimo, escuetos en el relato cronológico, y entra en Ovidio en busca de más información, citando expresamente las 'mudaciones' (sc. metamorfosis) allí acontecidas ${ }^{164}$. A continuación, la GE aborda cómo Juno, llevada por un carro celeste tirado por pavos reales, acudió ante Tetis y Océano -con un curioso e importante excurso sobre el término alumna ${ }^{165}-$ y denunció que Parrasis ${ }^{166}$ (sobrenombre de Calisto) hubiera sido convertida en estrella al mismo tiempo que su hijo (Arcas); vuelve al nacimiento de Arcas y cuáles fueron las dos estrellas en que resultaron trasformados madre e hijo, con muchos pormenores ${ }^{167}$; luego, la historia alfonsí se extiende en lo sucedido a Icario (el descubridor del vino), su hija Erígone y la perrilla de ésta, y cómo fueron convertidos en sendas constelaciones ${ }^{168}$. Hallamos, después, la mención de Filis-Demofonte y cómo ella, abandonada, le mandó una carta, de la que la GE nos da dos versos:

\footnotetext{
${ }^{159}$ GE I.13.15. En Ovidio, Fastos 4.793-794, aparecen relacionados ambos personajes míticos.

${ }^{160}$ Cf. Éxodo 23.28.

161 Véase GE I.15.31, donde leemos scrabones, grafía con error o deformación, que correspondería a un supuesto e inexistente scrabo. Para crabro, -nis, cf. Ovidio, Met. 15.368-374.

${ }^{162}$ GE I.16.25. Véanse, Ovidio, Met. 1.5; 23;85.

${ }^{163} G E$ I.20.31. El pasaje cita tres veces al poeta. Véase, Ovidio, Met. 1.72-75. El texto latino comúnmente aceptado difiere en varios elementos del alfonsí: en éste leemos, por ejemplo, seis animalibus, por suis animalibus.

${ }^{164}$ GE I.21.3, con tres alusiones al latino. A propósito de Arcas, acúdase a Ovidio, Met. 2.495-541.

${ }^{165}$ Met. 2.527. Lo dice Juno respecto a Océano-Tetis, pues, durante su niñez, habían sido sus padres adoptivos. La GE lo entiende como 'sobrina' y da una explicación detenida.

${ }^{166}$ Sobre ésta, GE I.21.16. Lo expuesto corresponde a Ovidio, Rem. 150.

${ }^{167} G E$ I.21.10-13, donde se cita cinco veces al poeta; y, además, 16-17. Para el relato de Ovidio sobre Calisto (nunca mencionada en las Metamorfosis con este nombre), acúdase a Met. 2.400-495.
}

${ }^{168}$ A saber, Boyero, Virgen y Can. Los hechos están recogidos en GE I.21.14-15; 18; 24-26. Respecto a Icario y Erígone, léase Met. 10.450-451. 
Hospita, Demofoon, tua te Rodepeya Pillis ultra promissum tempus abesse cueror ${ }^{169}$. E quieren estos viessos dezir en el lenguage de Castiella d'esta guisa: O tú Demofoón, yo Pilis de Ropede, la tu huéspeda, me querello de ti porque es passado el tiempo que me prometist e somos ya allend e tú non eres tornado a mí.

Pasamos ahora a Dárdano, rey de Troya: «El rey Júpiter, assí como cuenta el Libro de las Generaciones de los gentiles e Ovidio en el Libro de los días faustos, ovo a Electra, fija de Atlant, rey de las Españas e de Maya, fija de Mercurio, e fizo en ella a este rey Dárdano» ${ }^{170} ; \mathrm{y}$, finalmente, en el prólogo al libro 26 de la GE, leemos, entre los asuntos del mismo:

E de cómo falló Ovidio en griego el romanz de las dueñas yl ovo trasladado en el latín; e entre las otras epístolas de las dueñas que fizo d'éll cómo compuso ý una por esta Ipermestra d'aquellas razones que ella embió dezir a su marido seyendo en la prisión e aún después que salió d'ella ${ }^{171}$.

\subsection{Pompeyo Trogo $(11)^{172}$.}

Por lo que a nosotros nos afecta, Cneo Pompeyo Trogo (¿28 a.C.-14 d.C.?), cuyo padre había sido secretario de Julio César, escribió en los años de Augusto unas Historias Filípicas, compuestas de 44 libros, así llamadas porque el asunto central de las mismas fue el imperio macedónico y su fundador, Filipo, el padre de Alejandro. La obra comenzaba con el reino asirio de Nino, Persia, Macedonia, los reinos helenísticos, Roma y sus reyes, y llegaba hasta los años del citado Augusto. El texto original se perdió, pero nos ha llegado un resumen hecho por Marco Juniano Justino, del que hablaremos.

3.7.1. La primera mención de Trogo la leemos en GE I.8.6, a propósito del bíblico José.

3.7.2. El segundo contexto en que aparece dicho antropónimo es en GE I.13.4-5, donde, en escaso espacio, lo leemos diez veces, de las que recojo una selección:

Fallamos en estorias de los nuestros latinos que tres sabios fueron que escrivieron en arávigo mayormientre que otros a aquella sazón que esto fue las estorias de los fechos de amas las Egiptos e de todas aquellas tierras. E el mayor d'ellos e primero ovo nombre Pompeyo, e el II ${ }^{\circ}$ Cornel, el tercero Justino. Mas Pompeyo e Cornel escrivieron las estorias e Justino abrevió, esto es encortó, aquellas estorias que Pompeyo e Cornel escrivieron,

${ }^{169}$ GE I.22.22. Véase Ovidio, Her. 2.1-2. Encontramos varias discrepancias respecto al texto hoy común: Demophoon, Rhodopeia Phyllis, queror.

${ }^{170}$ GE I.22.23. Acúdase a Ovidio, Fast. 4.31-32.

${ }^{171}$ GE I.28.prólogo. No he encontrado argumentos suficientes que sostengan la opinión del texto alfonsí en el sentido de que Ovidio hubiera traducido desde el griego el contenido de las Heroidas.

172 Sobre la presencia de Pompeyo Trogo y su compilador Justino en la GE, cf. Eisenberg (1973), Saquero Suárez-Somonte-González Rolán (1993). 
peró las de Pompeyo, mas non las de Cornel. E en cabo todas fincaron escritas las unas e las otras. D'éstos retrae sobr'esta razón Paulo Orosio en el IX capítulo del su primero libro de las Estorias de los gentiles ${ }^{173}$ que dixieron aquel Pompeyo e Cornel cómo vinieran sobre Egipto aquellas plagas que avemos dichas tan grandes e tan desmesuradas de mal que non era yente en el mundo que sofrir las pudiesse ${ }^{174}$.

La GE, en el citado lugar, sigue hablando de Pompeyo y Justino, ajustándose bastante al texto de Orosio.

3.7.3. La última mención la ofrece la GE en I.12.7, a propósito de un hombre al que Moisés dio muerte, y, asimismo, de cómo el faraón murió en el mar durante la persecución de los hebreos. Tras recoger el relato dado por ciertas fuentes árabes, el texto alfonsí nos indica: «E esto assí lo razonan aquellos arávigos, e d'esta guisa fablaron de Moisén e de los otros ebreos sobre la salida de Egipto estos arávigos e caldeos, e tenemos que éstos se acogieron más e mejor a la verdad que Pompeyo e Justino nin Cornel».

\subsection{Muciano (1).}

Gayo Licinio Muciano, tres veces cónsul (la última en el 72 d. C.), tuvo altos cargos con Vespasiano a cuyo lado estuvo en Judea, antes de la guerra judaica. En el campo que nos interesa fue autor de escritos geográficos y se interesó por los asuntos maravillosos. Plinio lo cita en 52 ocasiones. Ya lo hemos mencionado en el apartado 2.1.2.

\subsection{Plinio $(138)^{175}$.}

3.9.1. Plinio el Viejo vivió entre los años 23-59 d. C. Su presencia es muy importante en la GE, donde, con frecuencia, se dice el libro y capítulo de la «Natural Estoria». En la parte estudiada lo hemos localizado en 138 contextos. Ya hemos visto bastantes referencias (véanse nuestros apartados 2.1.1, 2.1.2, 2.6, 2.9, 2.11, 2.14, 2.26, 2.32.4).

3.9.2. Ahora recogeré los más relevantes de los pasajes no nombrados, siguiendo el curso de la historia que estudiamos. Lo encontramos a propósito del tamaño de

\footnotetext{
${ }^{173}$ Orosio, Historiae adversus paganos 1.10. Podemos afirmar que lo que la $G E$ nos dice tanto de Pompeyo Trogo como de Justino está tomado de la citada obra de Orosio. Nos llama la atención que la GE considere autores arábigos tanto a Pompeyo (y a Cornel. Es decir, Tácito) como a Justino, si el equipo tenía a mano el texto latino de Orosio, donde se deduce fácilmente que ambos escritores eran romanos y habían escrito en latín.

${ }^{174}$ Cf. Justino, 36.2 .

${ }^{175}$ Para su presencia e influencia en España, véanse Rico (1972, pp. 127, 177), Eisenberg (1973), Casas Rigall (1999, pp. 165, 233), y Moure Casas (2008).
} 
Asia ${ }^{176}$, la fuente Nigris ${ }^{177}$, el tema de que sólo el hombre precisa de vestidos, pero no los demás animales ${ }^{178}$; en torno a diversos juicios sobre las imágenes e ídolos ${ }^{179}$; respecto a Europa:

cómo era la mejor e la más temprada tierra del mundo, e la más abondada de muchas buenas cosas, ca tal es Europa, e entre muchas buenas tierras que a en ella la provincia de Guadalquevir es la mejor, e aun de cuantas otras en el mundo son, assí como dize Plinio en el tercero libro ó departe d'estas tres tierras, Europa, Asia e África, e de las provincias d'ellas $^{180}$.

Leemos noticias de interés en punto a las personas de enorme estatura ${ }^{181}, \mathrm{y}$, también, en lo concerniente al ave Fénix y dónde vive ${ }^{182}$; y de los manantiales del Nilo $^{183}$. Se nos habla de Júpiter como planeta ${ }^{184}$; y de lo concerniente al Bósforo ${ }^{185}$, la magnitud de Egipto y cómo la divide el Nilo ${ }^{186}$. Otros elementos de indudable interés son el cocodrilo ('cocadriz', en Alfonso), mangosta, delfines del Nilo y otros animales ${ }^{187}$; el monte Atlas y otros hechos que allí suceden ${ }^{188}$; el río Anat ${ }^{189}$. Siguen más datos sobre el Atlas ${ }^{190}$, el toro Apis de Egipto ${ }^{191}$ y el Nilo como frontera entre Egipto y Etiopía ${ }^{192}$. Asimismo, a propósito del ibis y cómo se purga a sí mismo ${ }^{193}$, y en torno al Nigris (ya río, sin decirlo expresamente) y las gentes («los atlantas, los egipcianos, los semferos,

${ }^{176} G E$ I.2.23. Léanse en Plinio, NH 3.3.1, 6.33, 6.209-210, etc.

${ }^{177} G E$ I.3.4.

${ }^{178}$ GE I.3.11. Acúdase a Plinio, $N H$ 7.2.

${ }^{179}$ GE I.3.17. Consúltese Plinio, $N H$ 2.6-7.

${ }^{180}$ GE I.3.21. Véase Plinio, $N H$ 3.3-5, sobre Europa, allí elogiada. En cambio en 3.6, dedicado a Hispania, hace una descripción geográfica, pero no dice nada elogioso de ninguna de sus partes.

${ }^{181}$ GE I.3.23.Cf. $N H$ 7.73-75.

${ }^{182} G E$ I.4.2: «e sobre Caldea más arriba a parte de oriente tierra de Aravia, ó son los árvoles en que nacen las muchas especias e de muy buenas oluras e de grandes virtudes, e ó dize Plinio e otros filósofos e naturales que mora ell ave Fénix, que vive d'aquellas especias e non de ál». Véase $N H$ 10.3.1; 10.5.1; 12.85.1; 13.42.6; 29.29.1.

${ }^{183}$ GE I.5.14. Consúltes, $N H 5.53$.

${ }^{184}$ GE I.6.21. En $N H 2.35$.

${ }^{185} G E$ I.6.28. En la obra alfonsí leemos: «E es Bosforo cosa de que fabla el Plinio e otros muchos sabios». Cf. NH 4.76.9, donde distingue dos, el cimerio y el tracio. Nombra el término Bosporus en 32 secuencias.

${ }^{186}$ GE I.7.7, con dos menciones. Cf. NH 5.48.

${ }^{187} G E$ I.8.14-15, con cinco menciones del naturalista. Cf. $N H$ 8.89-93.

${ }^{188} G E$ I.10.21-23, donde se nombra seis veces al autor romano. Véase $N H$ 5.5.10-16.

${ }^{189} G E$ I.10.25. Dicho río ya lo hemos visto en el apartado 2.17 .

${ }^{190} G E$ I.10.16-17. Con cuatro menciones del prosista romano.

${ }^{191} G E$ I. 11.9-12. Con siete menciones del naturalista. Cf. $N H$ 8.184-186. La GE recurre, además, a otras fuentes.

${ }^{192}$ GE I.11.36. Consúltese $N H 5.48$.

${ }^{193}$ GE I.11.38. 
los plemios, los grantafantes, los sátiros, los imantopades») que vivían junto a él ${ }^{194}$. Nos llaman la atención no pocos detalles sobre esos y otros pueblos, muchos de ellos imaginarios: trogloditas, garamantes, blemnios y farusos ${ }^{195}$. Y en punto a la mirra se indica: «e leemos que á ý tres maneras de mirra, o aun cuatro, segund vos contaremos adelant assí como lo fallamos en la natural estoria que compuso Plinio» ${ }^{196}$. Se menciona también la púrpura ('pórpola', en GE) ${ }^{197}$. En el mundo animal, las indicaciones a propósito de la menstruación ${ }^{198}$; la unión de leoparda y león, o de leona y leopardo; la condición sexual del león y cómo advierte si la leona ha estado con un leopardo; el león que se amansó ante las palabras de una cautiva; y quién fue el primero que amansó el león ${ }^{199}$. De la naturaleza de los tigres ${ }^{200}$; del lobo y de los llamados hombres-lobo, con varios relatos, y una curiosa etimología del término griego lýkos ('lobo', en griego); los perros que conviven con el hombre y algunos relatos sobre su fidelidad; la unión del perro con la tigresa y la loba; la nobleza y valentía de los perros de Albania; cuándo queda preñada la perra y la rabia de los perros. Medicinas contra la mordedura del perro rabioso ${ }^{201}$. El caballo y su inteligencia; cómo los altos príncipes enterraban al suyo; anécdotas sobre Bucéfalo, el caballo de Alejandro, y de otros famosos rocines; cuánto vive el caballo y cuándo queda preñada la yegua; su parto y la crianza del potrillo; la naturaleza del asno; la unión de éste con yegua y de caballo con asna ${ }^{202}$. La naturaleza de la oveja y el carnero; la lana y sus colores; la naturaleza de las cabras; la mezcla de carnero y cabra y de oveja y macho cabrío; los animales en los tres elementos (agua, tierra y aire); las uniones entre los pescados; las uniones entre aves y animales terrestres y de las aves entre sí; de la naturaleza de las mezclas en las cosas; de los tres poderes del alma ${ }^{203}$.

\footnotetext{
${ }^{194} G E$ I.11.39, con tres alusiones sobre el naturalista. Se mencionan también los garamantes y trogloditas, entre otros pueblos. $H N$ 5.43-45, donde hay comparar con cuidado la grafía del romano con lo ofrecido por la $G E$.

${ }^{195} G E$ I.11.40, con dos alusiones al romano. Véase $H N$ 5.45-46.

${ }^{196}$ GE I.15.85. Cf. $N H$ 24.159; 26.108.

${ }^{197}$ GE I.16.25. Véase $N H$ 9.125-127.

${ }^{198}$ GE I.19.11. Léase $N H$ 9.125-127.

${ }^{199}$ GE I.20.9. Con cuatro menciones del escritor (Desde 1.20 .9 hasta 1.20 .35 contamos con 82 alusiones del naturalista. Algunas ya las hemos visto). Consúltese NH 8.41-58.

${ }^{200}$ GE I.20.13. Acúdase a NH 8.66.

${ }^{201} G E$ I.20.14-19, con doce menciones del naturalista. Véase $N H$ 8.72-76, 80-84, 142-153.

${ }^{202} G E$ I.20.20-26. Con 19 citas del prosista romano. Cf. NH 8.154-175.

${ }^{203}$ I.20.27-35. Es una larga secuencia donde hallamos 30 menciones del escritor romano. Cf., especialmente, NH 8.187-209; 9.158-164; 10.1-2. Además, lo hallamos citado en varios lugares de los libros 9 (Peces), 10 (Aves), 18 (Cereales).
} 


\subsection{LUCANO $(7)^{204}$.}

Su corta vida transcurrió entre los años 39-65 d. C. Autor épico, su obra se tituló Bellum civile (y también Pharsalia), en la que se narra la guerra civil entre César y Pompeyo. De sus apariciones en la GE, hemos citado ya algunas, en el apartado 2.1.2 y en notas a 2.7 y 3.9.2. Veamos algunas más: «E dize otrossí Lucano en la estoria de Pompeyo el Grand e de Julio César ${ }^{205}$ que Arax es allí nombre d'un río, e lieva la tierra nombre d'él, como Iberia, que es por España, del su río Ebro» ${ }^{206}$. Luego, un pasaje largo en donde se habla del sacerdote Acoreo ${ }^{207}$, ya mencionado, dentro de una secuencia importante con tres menciones del épico:

E pues que sobr'el fecho del Nilo avemos movido razón queremos dezir en este logar cuanto ende fallamos, e contaremos lo que diz dend Lucano por sí e por el obispo Acoreo.

IX De la razón de Lucano sobr'el Nilo.

Cuenta Lucano en el dezeno libro de las batallas de los cibdadanos de Roma que pues que Pompeyo el Grand e Julio César, que fueron los grandes e muy nobles romanos, lidiaron, e fue vencido Pompeyo $[\ldots]^{208}$.

Por último, leemos así: «E aquí torna Lucano de Córdova de España a razónarse contra'1 obispo Acoreo <e> de cabo con Julio César en esta razón, e diz así» ${ }^{209}$.

\subsection{Estacio (2)}

Su vida suele situarse entre los años 45-96 d. C. Lo hemos visto ya en el apartado 2.6, a propósito del monte Atlas. En GE, texto revisado, no se mencionan ni las obras poéticas de dicho poeta ni los títulos de las mismas. Pero por las referencias que hemos podido aportar, debe acudirse a su Tebaida y sus Silvas. Nos queda otra cita del mismo, donde la GE nos dice a propósito de los faraones:

E otrossí porque avemos dicho en esta estoria muchas vezes de los faraones tebeos e non departimos aún en ningún logar donde ovieron este nombre queremos aquí departir dond le levaron, e fazer lo emos por razón de algunos que cuedan que fueron estos tebeos de la cibdad de Tebas la que pobló Cadmo, fijo del rey Agenor, assí como dizen Ovidio e Estacio e otros ${ }^{210}$.

\footnotetext{
${ }^{204}$ Acerca de la presencia de Lucano en Alfonso X, véanse RuBio ÁlvAREZ (1958), HerRERo LloRENTE (1957, 1959), LidA de MALKiel ( 1959-1960), Almazán (1963), Eisenberg (1973), etc.

${ }^{205}$ Le llama también "libro de las batallas de los cibdadanos".

${ }^{206}$ GE I.2.25. "Arax" es el Araxes, río de Armenia, citado en BC 7.188, 8.431.

${ }^{207}$ Ya visto en apartado 2.7.

${ }^{208}$ GE I.5.8-9. Siguen muchos detalles sobre la relación de Pompeyo con Ptolomeo Filopátor, y de César, con Cleopatra.

${ }^{209}$ GE I.5.16. A continuación, el capítulo 17 está dedicado a las palabras de César.

${ }^{210}$ GE I.7.7. Sobre Cadmo, cf. Ovidio, Met.3.3, 3.14, 3.24, 3.115, y así hasta 18 menciones; Estacio, Tebaida 1.6, $1.15,1.223$, etc, con un total de 34 lugares.
} 


\subsection{2. ТÁCITO $(16)^{211}$.}

Publio Cornelio Tácito vivió en los años 55-120. De sus cinco obras conservadas nos interesan aquí sus Historias. Hasta ahora hemos encontrado once citas en GE I.13.47, ya vistas. ${ }^{212}$ Acudo ahora a las otras menciones. La primera en GE I.5.31, en punto a la destrucción de Sodoma y Gomorra, más otras tres ciudades vecinas, y cómo todo, por castigo divino, quedó convertido en un lago: «D'este lago cuentan muchas cosas, e diz Cornelio que el agua d'él es empoçoñada, e que el baho que sale d'ella corrompe la tierra de aderredor de sí e fázela mañera» ${ }^{213}$. A continuación, algo después (GE I.5.32), tenemos otras dos citas. Por último, para GE I.19.6, véase Justino.

\subsection{Justino (8)}

3.13.1. Marco Juniano Justino Frontino floreció quizá en el III d. C. Hizo un resumen, con no pocas ampliaciones, de la obra de Pompeyo Trogo ya mencionada. Sus digresiones son muchas $\mathrm{y}$, con frecuencia, de propósito moralizador. Fue autor muy leído durante el Medievo.

3.13.2. Lo hemos visto ya en los apartados 3.7.1, 3.7.2 y 3.7.3. Nos queda un pasaje de GE I.19.6, donde, a propósito del leproso y la lepra ('gafo', 'gafez') y de las recomendaciones de la Biblia, leemos:

Onde vos contaremos agora aquí sobr'esto unas razones que cuenta Josefo contra Corneyo e contra Justino ${ }^{214}$, que escrivieran esta estoria en ell egipciano, e contra otros arávigos que lo escrivieron en ell arávigo; e dezir vos emos aquí esto sobre unas razones que vos contamos ya en la estoria del libro Éxodo e las non dixiemos ý todas ${ }^{215}$.

El texto alfonsí se extiende, a continuación, en un comentario sobre el criterio de Josefo en punto a la lepra. Lo que nos llama la atención es que se insista aquí en que Cornelio (en el pasaje 'Corneyo') y Justino hubieran escrito en árabe su relato, como ya lo vimos en el apartado 3.7.2.

\footnotetext{
${ }^{211}$ Para su presencia en la GE, véanse EISEnberg (1973), Codoñer (1990), SAquero SuÁrez-SomonteGonZÁLEZ RoLÁN (1993).

${ }^{212}$ Como «Cornel Tácito», lo tenemos una sola vez. El resto figura como Cornelio (1), Cornel (13), Corneyo (1). En el «Índice» (2015) parece entenderse que Cornel-Corneyo son distintos de Cornel Tácito.

${ }^{213}$ Orosio, Historiae adversus paganos 1.5. Éste autor cita en ese lugar al historiador romano (Cornelius Tacitus): Hist. 5.7.1 (Haud procul[...]reor. Con alguna omisión).También lo menciona en el cap. 10: Pompeius Corneliusque, más otras dos veces (Cornelius) y da otra cita de 5.3 (plurimi auctores[...]pepulissent), a la que sigue la interpretación de Orosio.

${ }^{214}$ Error histórico, pues son autores posteriores a Josefo.

215 Puede consultarse Justino, 36.2.12: Sed Aegyptii, cum scabiem et uitiliginem paterentur, responso moniti eum cum aegris, ne pestis ad plures serperet, terminis Aegypti pellunt. Dux igitur exulum factus sacra Aegyptiorum furto abstulit, quae repetentes armis Aegyptii domum redire tempestatibus conpulsi sunt. Orosio, 1.10, recoge ese texto, y lo refiere a Pompeyo Trogo o a Justino (Ait enim Pompeius, siue Iustinus, hoc modo)
} 
Juan Antonio López Férez

3.14. JERÓNIMO $(364)^{216}$.

3.14.1. Su vida suele fijarse entre los años 340-420 d. C. Autor de numerosas obras, me limitaré a dos títulos auténticos que aparecen aludidos en esta aportación: el Cronicón (en latín, traducido del griego, Chronicon (ya apuntado en 2.32.1) ${ }^{217}$ y la traducción de la Biblia al latín (la que mucho después se llamaría Vulgata) ${ }^{218}$. Ya lo hemos encontrado repetidas veces a lo largo de este trabajo.

3.14.2. Dado el elevado número de menciones, he creído que podría resultar útil para futuros estudiosos distribuirlas, sin ánimo de exhaustividad, de acuerdo con algunas peculiaridades.

3.14.2.1. Mención sólo junto a Moisés: I.1.3; I.6.11; I.8.12; I.9.15; I.11.2; I.12. prólogo; I.13.7; I.13.8; I.14.18; I.15.1; I.15.79; I.15.82; I.15.84 (2); I.16.2; I.16.8; I.16.11; I.16.17 (2); I.16.18; I.17.3 (2); I.17.11; I.17.17 (2); I.17.21; I.17.22; I.17.23; I.17.24; I.17.25; I.17.26; I.17.27; I.17.28; I.17.33; I.17.36; I.18.6; I.18.8; I.19.prólogo; I.19.1; I.19.4; I.19.5 (2); I.19.6; I.19.7; I.19.8; I.19.13; I.19.20 (2); I.20.prólogo; I.20.4; I.20.6 (3); I.20.34; I.20.36; I.20.41; I.20.44; I.20.53; I.21.1; I.21.2; I.22.prólogo; I.22.3; I.22.4; I.22.8; I.22.17; I.23.3 (2); I.23.7; I.23.29; I.24.3; I.24.6; I.24.7; I.24.15; I.24.16; I.24.17; I.24.18; I.24.19; I.24.22; I.24.23; I.25.3 (3); I.25.8; I.25.9; I.25.10; I.25.36 (2); I.25.37; I.25.38; I.25.42; I.26.8; I.27.5; I.29.21.

3.14.2.2. Jerónimo solo o junto a «los otros»: I.1.26; I.1.30; I.2.2; I.2.5; I.3.23; I.3.24; I.4.17; I.5.18; I.5.33 (3); I.6.9; I.6.10; I.6.11; I.6.16 (4); I.7.20; I.7.22 (3); I.9.39; I.12.1; I.14.23; I.14.33; I.15.75; I.15.78 (2); I.15.79; I.15.83; I.15.84; I.16.3; I.16.16; I.17.prólogo; I.17.13; I.17.15; I.17.20; I.20.41; I.20.53; I.20.56; I.20.60; I.21.prólogo (4); I.21.1; I.21.19; I.21.20 (2); I.22.6 (2); I.22.7; I.22.8; I.22.9; I.22.10; I.22.12 (2); I.22.19 (2); I.22.20; I.23.4; I.23.6 (2); I.23.8 ; I.23.13 (2); I.23.14; I.23.15; I.23.21; I.23.24; I.24.9; I.24.11; I.24.12; I.24.13; I.24.21; I.24.22; I.25.3; I.25.5; I.25.6; I.25.10; I.25.12; I.25.21; I.25.32; I.25.33 (2); I.25.34; I.25.35 (2); I.25.36; I.25.39; I.26.prólogo; I.26.1; I.26.9; I.26.11; I.26.17; I.26.19; I.26.21; I.26.22; I.26.24; I.26.26; I.26.27; I.27.6; I.27.8; I.28.1; I.28.5; I.28.8.

\footnotetext{
${ }^{216}$ Para la presencia e influencia de Jerónimo en Alfonso X, véanse, entre muchos, Rico (1972, pp. 22, 31, 51), Eisenberg (1973), Perona (1998), Fernández Ordóñez (1999, pp.119-120), etc.

${ }^{217}$ Partiendo de la obra de Eusebio amplió los datos hasta el 379 d. C. Comienza en Abrahán y termina en hechos de su propia época. Las tablas cronológicas fueron esenciales para el estudio de la historia universal. Su aportación fue el punto de partida para crónicas posteriores.

${ }^{218}$ El Papa Dámaso le recomendó a Jerónimo que revisara la traducción latina de la Biblia (la Vetus Latina), pero éste se decidió a hacerla de nuevo (en 382, entregó en Nuevo Testamento; en 405, acabó la versión del Antiguo). Los estudiosos indican que, aunque conocía la versión griega de los Setenta, entonces canónica en la Iglesia, prefirió partir del texto hebreo tradicional.
} 
3.14.2.2. Jerónimo “en la glosa» ${ }^{219}$, sin ningún otro autor: I.1.25; I.1.26; I.1.30; I.2.1 (2); I.2.25; I.4.5; I.4.15; I.5.2; I.6.8 (2); I.7.18; I.13.30; I.14.33; I.14.35.

3.14.2.3. Una selección. Junto a otro autor, sólo uno: la Biblia y Jerónimo: I.16.4; Isidro ${ }^{220}$ y Jerónimo: I.3.3; con Agustín: I.2.7; con «maestre Pedro»: I.6.4; I.6.6; I.6.9; I.7.18. Al lado de otros dos: con Moisés y Agustín, I.15.83; con los Setenta y Agustín: I.15.31; con Beda y Agustín: I.2.13; con Agustín y Gregorio: I.14.35.

3.14.2.4. En ocasiones se dice Moisés-Jerónimo, cuando la cita o comprobación procede de Eusebio-Jerónimo: I.6.11; I.6.11

3.14.2.5. Aparte de los citados, recojo algunas acumulaciones de fuentes: I.25.16: «como dizen los esponedores, como Augustín, Beda, Orígenes, Rabano, Jerónimo e los otros que d'esta razón» (6 fuentes); I.23.22: «E segund departen Jerónimo e Agustín e Josefo e maestre Pedro e Orígenes e Rabano e otros» (7 fuentes); I.21.prólogo: «Pues de la primera de todas estas razones fablaron Moisén e Josefo e Jerónimo e Teodocio e los LXX Trasladadores, e los esponedores d'ellos, como Augustín, Orígenes, Beda e maestre Pedro e otros muchos» (10 fuentes); I.12.23: «E sobre aquellas razones que vos dixiemos fasta aquí que dixieron en este fecho Moisén e Josefo e maestre Pedro e maestre Godofré fallamos algunas razones más que dixieron ý Agustín, Jerónimo, Beda, Rabano, Strabo, Ambrosio e Paulo Orosio e otros escritos de arávigos» (12 fuentes).

\subsection{Agustín $(52+32$ Augustín=84) 221 .}

3.15.1. Los años 354-430 son los correspondientes a su vida. La GE, de entre la nutrida producción del citado, sólo menciona una obra por su título, a saber, dos veces la Ciudad de Dios. Por lo demás abundan las citas con respecto a comentarios bíblicos ${ }^{222}$,

\footnotetext{
${ }^{219}$ Desde el siglo XII se denomina «la Glosa» a las exegesis medievales que enriquecieron el texto latino de la Biblia parisina. La editio princeps de la Biblia latina cum glossa ordinaria fue publicada en Estrasburgo, Adolph Rusch, 1480-1481, en cuatro volúmenes. La Patrologia Latina de Migne, volúmes 113 y 114, ofrece una versión del siglo XII (falsamente atribuida durante siglos a Walafrido Strabo, que vivió en 805-849). La Glossa ordinaria puede consultarse en línea: https://gloss-e.irht.cnrs.fr/php/livres-liste.php. Por otro lado, en la $G E$ «la glosa» puede referirse también al proceso de traducción y conversión del texto latino para la versión castellana realizada por el equipo alfonsí, como se ha visto en el caso de las Heroidas ovidianas presentes en la General Estoria.

${ }^{220}$ Isidoro de Sevilla.

${ }^{221}$ Sobre la presencia de Agustín de Hipona en la GE, cf. Rico (1972, pp. 3, 73), Eisenberg (1973) de LuIS Vizcaino (2002), SÁnchez-PRieto BorJa (2015).

${ }^{222}$ Por ejemplo, la venerable Patrologia latina recoge en los volúmenes 32-44 la enorme producción literaria de Agustín. Para nuestro trabajo son de especial interés sus aportaciones sobre el Génesis (De genesi..., 4 títulos), y acerca de los tratados bíblicos contenidos en la parte que revisamos (más dos de la parte segunda), a saber: In Heptateuchum, con 2 títulos.
} 
bien de sólo dicho autor, bien de varios. La GE también lo trae a colación a propósito de la glosa. A lo largo de esta aportación ya hemos encontrado varias veces a este autor.

Por lo demás, con el ánimo de ser útil a futuros investigadores, divido las citas en varios apartados, sin ánimo de ser exhaustivo.

3.15.2. Agustín solo: GE I.12.15; I.13.8; I.14.8; I.14.22; I.14.24; I.14.25; I.14.26; I.14.27; I.14.28; I.14.29; I.14.30; I.14.31 (5 casi seguidos); I.14.34; I.15.2; I.15.24; I.15.55; I.16.10; I.16.24; I.17.25; I.18.7 (3, casi seguidas); I.19.11; I.22.15 (2).

3.15.3. Agustín solo, pero aludiendo, en concreto, a la Ciudad de Dios: I.6.27; I.4.9.

3.15.4. Agustín solo, pero referido a la glosa: I.3.19; I.5.5; I.6.6; I.12.26 (2); I.14.8; I.14.34; I.15.2 (2); I.15.31; I.20.45; I.22.17; I.24.8.

3.15.5. Agustín con otro: Jerónimo, I.2.5; I.2.7. Rabano: I.12.15; «Maestre Pedro»: I.3.19; I.14.22; etc.

3.15.6. Agustín y otro autor, más el término «otros»: I.9.33: «De lo ál que dixo adelant que era fermoso de vista e que corrién las fijas sobr'el muro dizen otrossí sant Agustín e maestre Pedro e otros que fue dicho porque Josep era tan fermoso que vencié de fermosura a todos los otros omnes d'aquella sazón»; I.1.14; I.14.23; I.14.24.

3.15.7. Agustín y muchos (cuatro o más): I.23.22: «E segund departen Jerónimo e Agustín e Josefo e maestre Pedro e Orígenes e Rabano e otros» (7); I.15.82: «Moisén e Jerónimo e Josefo e Agustín e Orígenes e maestre Pedro e maestre Godofré, e los otros que d'él fablaron» (8); I.17.25: «Assí como lo avemos por los escritos de Moisén e de Jerónimo e de Josefo e de maestre Pedro e por los dichos de Agustín e de Orígenes e de Beda en las glosas e de todos los otros esponedores, e assí lo otorgan Teodocion en su traslado e los LXX trasladadores en el suyo» (10); I.21.prólogo: «Pues de la primera de todas estas razones fablaron Moisén e Josefo e Jerónimo e Teodocio e los LXX Trasladadores, e los esponedores d'ellos, como Augustín, Orígenes, Beda e maestre Pedro e otros muchos» (10).

\subsection{Orosio (58) $)^{223}$.}

3.16.1. La vida de Paulo Orosio suele encuadrarse entre los años 383-420. De entre su producción, para nuestro trabajo, sobresalen sus Historiarum adversum paganos libri VII, a los que, en una ocasión, la GE (1.13.4) llama «Las Estorias de los gentiles».

${ }^{223}$ Para la presencia e influencia de Orosio en la GE, cf. LIDA DE MALKIEL (1959-1960), JimÉnez (1972), EISENBERG (1973), JimÉNEZ VicENTE (1993), AlmEIDA (2018), etc. 
Algunas notas sobre la recepción de autores griegos o latinos en la General Estoria de Alfonso X [...]

Dicho escrito abarcó la historia universal desde los comienzos hasta los días del escritor, y tuvo una gran repercusión en los siglos siguientes, no sólo por los muchos datos aportados sobre los pueblos paganos, sino también por la metodología y claridad seguidas al exponerlos. Ya lo hemos visto en apartados 2.1.2 y 2.32.4 (5), 3.7.2 y 3.14.25 .

3.16.2. Por lo demás, con el ánimo de ser útil a futuros investigadores, divido las citas en varios apartados, sin ánimo de ser exhaustivo.

3.16.3. Orosio solo: I.2.23: «Africa otrossí comiença en el so algarbe en el mont Atlant e en el mar Atlántico, segund diz Orosio»; I.3.28 (2)(sobre Nino); I.3.30 (10) (notable acumulación a propósito de los cuatro reinos principales del mundo); I.4.2 sobre Mesopotamia; I.4.21; I.4.24: «e dize Paulo Orosio en el cuarto capítulo del primero libro que tanto era fuerte esta reína Semíramis que semejava a su marido en el esfuerço e en la fortaleza del coraçón, e en la cara e en el vestir al fijo»; I.4.25, Semíramis llega a la India:

«E cuenta Orosio que nunca otro lidiador nin guerrero entró a India fueras ende esta reína e el grand Alexandre»; I.4.38: sobre la unión de Semíramis con su hijo.

3.16.4. Citado junto a otro. Platón: I.13.14 (2. Importante por el crédito que la GE le da a Orosio):

E fue Fetón ende rey, assí como lo fallamos en los autores de los gentiles, e contecieron otrossí estonces muchas otras pestilencias grandes por muchas otras tierras, assí como dizen Plato e Orosio e otros que lo retraen por ellos; [...] mas Paulo Orosio, que fue sacerdot e omne bueno e de creer e santo, pone estas pestilencias en el IX ${ }^{\circ}$ capítulo del su primero libro que fizo de los fechos de los gentiles, e cuéntalas después de las plagas de Egipto mostrando que cuando Nuestro Señor Dios firió a Egipto que firió otrossí en essa sazón misma muchas otras tierras porque creyén todos en dioses de vanidades e en ídolos...

3.16.5. Con varios autores: I.13.4 (2); I.13.5 (2); I.13.9 (7 veces. A propósito de las plagas padecidas por los egipcios). 


\section{Bibliografía}

FuENTES $^{224}$.

\section{LiterATURA GRIEGA}

\subsection{GENERAL}

Patrologia Graeca, ed. J. P. Migne, París, J. P. Migne, 1857-1866 (161 volúmenes, y un índice general).

TLG=ThesAurus LiNGUAE GRAECAE (2001¹). University of California. Irvine (California) (en línea. Imprescindible para búsquedas de léxico).

\subsection{UN AUTOR ESPECIAL}

JOSEFO

Flavii Josephi Opera, eds. A. P. Arlenius-S. Gelenius, H. Froben-N. Episcopius, Basilea, Hieronymus Froben,1544 (Editio princeps).

Flavius Josephus, Antiquitates Judaicae, Rufinus aquileiensis interpres (?), 1400-1450, manuscrits (Consultado en gallica.bnf.fr). Revisada, asimismo, la impresa, junto con otras obras de Josefo, en Venecia, Albertino Vercellese, 1499 (La ofrece la Biblioteca Valenciana, Digital. Es similar a Flavius Josephus, De antiquitate Judaica. De bello Judaico, Trad. Rufinus Aquileiensis, ed. Hieronymus Squarzaficus, Venecia, Albertinus Vercellensis, para [los herederos de] Octavianus Scotus, 23 Oct. 1499. $\mathrm{f}^{\circ}=$ tij00487000, Bodleian Library, University of Oxford).

FLAVIUS JOSEPHUS, De antiquitate judaica. De bello judaico. Contra Apionem, Reynaldus de Novimagio, Venecia, 1481 (fue la primera vez en que se publicaron juntas las traducciones de esas tres obras).

BLATT, F., The Latin Josephus. I. Introduction and Text: The Antiquities, Books i-v (Acta Jutlandica, xxx. I.). Aarhus, Universitetsforlaget, Copenhague, Munksgaard, 1958.

THE LATIN JOSEPHUS PROJECT [Con información relevante sobre ediciones y traducciones del historiador judío. Puede verse en https://sites.google.com/site/ latinjosephus/antiquities y en AWOL-The Ancient World Online. Desde el 12 de marzo de 2018, este instrumento, muy recomendado, gratis, con respecto a las Antiquitates Iudaicae, en la misma página, ofrece tres textos: la transcripción latina del manuscrito Bamberg Msc. Class. 78 (de mediados del IX), el texto

\footnotetext{
${ }^{224}$ Sólo las especiales. En general, no he recogido bibliografía específica de cada uno de los autores griegos o romanos, a no ser que estuvieran íntimamente relacionados con la GE. Tampoco he mencionado los útiles imprescindibles para trabajar en los autores griegos o latinos, tanto en el terreno lingüístico como en el literario. Por mor de brevedad he usado con frecuencia las abreviaturas de obras griegas o latinas, fáciles de conseguir hoy en internet.
} 
Algunas notas sobre la recepción de autores griegos o latinos en la General Estoria de Alfonso X [...] griego de Niese (Flavii Iosephi Opera, vol. 1.1887; y la traducción inglesa de William Whiston, 1737].

\section{LITERATURA LATINA}

\subsection{GENERAL}

Classical Latin Texts. A Resource Prepared by The Packard Humanities Institute $2011^{1}$ (última revisión 2015. http://latin.packhum.org (En línea. Imprescindible para búsquedas de léxico. De uso libre).

Patrologia Latina, ed. J. P. Migne, París, J. P. Migne, 1844-1855 (217 volúmenes, más 4 volúmenes de Índices, 1862-1865).

\subsection{AutORES}

JERÓNIMO

El Cronicón puede consultarse, con el texto latino y traducción inglesa, en https:/ / www.fourthcentury.com/jerome-chronicon. Aquí se tiene acceso a:

1. http://www.tertullian.org/fathers/jerome_chronicle_04_latin_prefaces. htm (que ofrece el texto latino de HELM, R. Die Chronik des Hieronymus=Hieronymi Chronicon, GCS 47=Eusebius' Werke 7 (Berlín, Akademie-Verlag, 1956). Presenta el texto electrónico de la Patrologia Latina, corregido con la edición de J. K. Fotheringham (Eusebii Pamphili Chronici canones latine vertit, adauxit, ad sua tempora produxit S. Eusebius Hieronymus, Londres, Humphrey Milford, 1923);

y 2. http://www.tertullian.org/fathers/jerome_chronicle_00_eintro.htm (A saber: M. D. Donalson, A translation of Jerome's Chronicon with historical commentary, Lewiston, Mellen University Press, 1996

JUSTINO

Marcus Junianus Justinus, Epitome of the Philippic History of Pompeius Trogus, trad. \& notas J. Selby Watson, Londres-Nueva York, Henry G. Bohn-Convent Garden, 1853 (en línea; bilingüe, latín-inglés).

OrOSIO

Pauli Orosil, Aduersus paganos historiarum libri septem, ed. F. F. Marcodurano, Colonia, Materno Cholino, 1573 (en línea: BNE). 
2.3. Literatura medieval (Dos autores Relevantes).

Juan De Garland

Giovanni di Garlandia, Integumenta Ovidii, ed. F. Ghisalberti, Mesina-Milán, Giuseppe Principato, 1933.

\section{Godofredo De Viterbo}

Pantheon. Consultado en Gotifredi Viterbiensis Opera, dentro de los Monumenta Germaniae Historica. Rerum Germanicarum Scriptores Aliquot Insignes... J. Pistorius-B. G. Struve (eds.), Rastibona, J. C. Peezii, $1776^{3}$, vol. 2).

\section{General Estoria}

Texto utilizado: P. Sánchez-Prieto Borja-R. Díaz Moreno-E. Trujillo Belso: Edición de textos alfonsíes en REAL ACADEMIA ESPAÑOLA: Banco de datos (CORDE) [en línea]. Corpus diacrónico DEL español. <http:/ / www.rae.es> [7 de marzo 2006].

\section{Estudios}

Almeida Cabrejas, B., "La sección no conservada de la Quinta Parte de la General Estoria: contenido, fuentes, problemas textuales", en J. Cañas Murillo - F. J. Grande Quejigo-J. Roso Díaz (eds.), Medievalismo en Extremadura. Estudios sobre Literatura y Cultura Hispánicas de la Edad Media, Cáceres, Universidad de Extremadura, 2009, pp. 461-472.

, "Índice de nombres propios de la Primera parte de la General Estoria", Lemir 19 (2015), pp. 281-360 (En este trabajo=Índice).

, "Maldad y pecado en la General estoria de Alfonso X El Sabio", Revista de El Colegio de San Luis 6.12 (2016), pp. 10-38.

, "Traducción de Orosio en las estorias alfonsíes: reflexiones sobre el uso de una fuente "fácil", en S. del Rey Quesada - F. del Barrio de la Rosa - J. González Gómez (coords.), Lenguas en contacto, ayer y hoy. Traducción y variación desde una perspectiva filológica, Berlín, Peter Lang, 2018, pp. 97-116.

y Trujillo, E. “Censura y modificación ideológica en la Quinta Parte de la General Estoria de Alfonso X el Sabio", Diálogo de la Lengua 1 (2008), pp. 1-14.

Alvar, C., Traducciones y traductores: materiales para una historia de la traducción en Castilla durante la Edad Media, Alcalá de Henares, Centro de estudios cervantinos, 2010. Avenoza, G., "Algunos libros de la biblioteca de Lope García de Salazar", Revista de filología española 83, 1-2 (2003), pp. 5-37.

Bautista, F., "Alfonso X, Bernardo de Brihuega y la General estoria", Atalaya 17, (2017) (en línea).

Bizarri, H. O., La otra mirada: el "exemplum" histórico, Zúrich, LitVerlag, 2019. 
Algunas notas sobre la recepción de autores griegos o latinos en la General Estoria de Alfonso X [...]

Casas Rigall, J., La materia de Troya en las letras romances del siglo XIII hispano, Universidade de Santiago de Compostela, 1999.

, "Sobre la adaptación de Ilias Latina en el Libro de Alexandre y cuestiones conexas (de Dictis y Dares a Alfonso X)", en S. Fortuño Llorens-T.Martínez Romero (eds.), Actes del VII Congrés de l'Associació Hispànica de Literatura Medieval (Castelló de la Plana, 22-26 de setembre de 1997), Castelló de la Plana, Publications de la Universitat Jaume I, 1999, 2, pp. 39-54 (1999a).

Castillo Lebourgeois, N. del, "Griegos y troyanos en la General Estoria alfonsí", en M. T. Muñoz García de Iturrospe-L. Carrasco Reija (eds.), Miscellanea latina, Madrid, Sociedad de Estudios Latinos-Universidad Complutense de Madrid, 2015, pp. 452-459.

CODOÑER, C., "Las primeras traducciones latinas del latín al romance: la General Estoria", en F. Villar (ed), Studia Indogermanica et Palaeohispanica in Honorem A. Tovar et L. Michelena, Salamanca, Universidad del País Vasco-Universidad de Salamanca, 1990, pp. 183-194.

Coulson, F. - Roy, B., Incipitarium Ovidianum. A finding Guide for Texts related to the Study of Ovid in the Middle Ages and Renaisance, Turnhout, Publications of the Journal of Medieval Latin, 2000.

Cristóbal, V., “Ovid in Medieval Spain”, en J. G. Clark-F. T. Coulson - K. L. McKinley (eds.), Ovid in the Middle Ages, Cambridge, Cambridge University Press, 2011, pp. 231-256.

, "Orfeo y otros mitos eróticos en la General Estoria", Cahiers d'études hispaniques médiévales, 38.1 (2015), pp. 65-89.

Cuesta Torre, M. L., “Los comentaristas de Ovidio en la General Estoria II, caps. 74115", Revista de Literatura 19 (2007), pp. 137-169.

Díez De Revenga, F. J., “Literatura en las obras históricas de Alfonso X el Sabio”, Mester 17.2 (1988), pp. 39-50.

EisenberG, D., “The General Estoria: Sources and Source Treatment”, Zeitschrift für romanische Philologie 89 (1973), pp. 206-227.

EKMAN, E., "Ovid Historicized: Magic and Metamorphosis in Alfonso X's General estoria", La corónica. A Journal of Medieval Hispanic Languages Literatures and Cultures 42.1 (2013), pp. 23-46.

Feldman, L. H., Josephus and Modern Scholarship (1937-1980), W.de Gruyter, BerlínNueva York, 1984.

Fernández OrdóñEz, I., Las "Estorias" de Alfonso el Sabio, Madrid, Istmo, 1992.

, "El taller historiográfico alfonsí. La Estoria de España y la General Estoria en el marco de las obras promovidas por Alfonso el Sabio", en J. Montoya-A. Rodríguez (coords.), El Scriptorium alfonsí: de los Libros de Astrología a las Cantigas de Santa María, Madrid, Fundación Universidad Complutense, 1999, pp. 105-126. 
FraKer, Ch., The Scope of History: Studies in the Historiography of Alfonso El Sabio, Ann Arbor, The Michigan University Press, 1996.

"Rhetoric in the Estoria de Espanna of Alfonso el Sabio", Talia dixit, 1 (2006), pp. 81-104.

Francomano, E. C., “Castilian Vernacular Bibles in Iberia, ca. 1250-1500”, en S. Boynton

- D. J. Reilly (eds.), The Practice of the Bible in the Middle Ages: Production, Reception, and Performance in Western Christianity, Nueva York, Columbia University Press, 2011, pp. 315-337.

GinzLER, J. R., The role of Ovid's Metamorphoses in the General Estoria of Alfonso el Sabio (Tesis), Madison, University of Wisconsin. 1971.

Gómez FariñA, L., "Atlas: la reescritura de un mito a través de los siglos", en C. Esteve Mestre (ed.), El texto infinito: tradición y reescritura en la Edad Media y el Renacimiento, Salamanca, SEMYR, 2014, pp. 577-588.

Gómez Jiménez, M., Proyección del mito de Circe en la literatu ra hispánica: de la época medieval a la contemporaneidad (Tesis), Universidad Complutense de Madrid, 2018.

GonzÁlez DíAz, S., Del Génesis a los Andes: Una lectura del diluvio y las cronologías del incario a través de las crónicas (siglos XVI-XVII), (Tesis), Universidad Autónoma de Barcelona, 2014.

Impey, O. T., “Ovid, Alfonso X, and Juan Rodríguez del Padrón: two Castilian translations of the Heroides and the beginnings of Spanish sentimental prose", Bulletin of Hispanic studies 57.4 (1980), pp. 283-297.

Jiménez, M. C., Paulus Orosius in Alphonsus X the Wise (Tesis), The University of Michigan, 1972.

Jiménez Vicente, M. C., La razón de estado en Alfonso X el Sabio: Paulo Orosio en la Primera crónica general, Universidad de Valladolid, Secretariado de Publicaciones, 1993.

Lauriola, R. - Demetriou, K. N. (eds.), Brill's Companion to the Reception of Euripides, Leiden-Boston, Brill, 2015.

Lida De Malkiel, M. R., “La General Estoria: notas literarias y filológicas (I)”, “La General Estoria: notas literarias y filológicas (II)", Romance Philology, 12 (1958-1959), pp. 111-142; 13 (1959-1960), pp. 1-30.

"Josefo en la General Estoria", en F. Pierce (ed.), Hispanic Studies in Honour of I. Gonzalez Llubera, Oxford, Dolphin Book, 1959, pp. 163-181.

LóPEz FÉrez, J. A., “Datos sobre la influencia de la épica griega en la literatura española”, en Id. (ed.), La épica griega y su influencia en la literatura española, Madrid, Ediciones Clásicas, 1994, pp. 359- 409.

"Memoria histórica y tradición clásica en la General Estoria de Alfonso X el Sabio (Primera Parte)" en I. Grifoll-J. Acebrón-F. Sabaté (eds.), Cartografies de l'ànima: identitat, memòria i escriptura, Lleida, Pagès editors, 2014, pp. 173-200. "Mitos y nombres míticos clásicos en la General Estoria de Alfonso X (Primera y segunda partes)", en J. De la Villa Polo et alii (eds.), Ianua classicorum. Temas 
Algunas notas sobre la recepción de autores griegos o latinos en la General Estoria de Alfonso X [...]

y formas del mundo clásico. Actas del XIII Congreso español de Estudios clásicos, Madrid, SEEC, 3 (2015), pp. 469-526.

López FonsecA, A. - Ruiz Vila, J., “De las crónicas o tienpos; de Eusebio-JerónimoMadrigal: edición crítica de una adición inédita en la traducción", Cuadernos de Filología Clásica. Estudios Latinos, 39.1 (2019), pp. 43-67.

Luis Vizcaíno, P. de, "Las traducciones al castellano de San Agustín”, en A. Bueno García-C. Adrada Rafael (eds.), La traducción monacal: valor y función de las traducciones de los religiosos a través de la historia. Actas del coloquio internacional, Soria, Diputación Provincial de Soria, 2002, pp. 125-148.

Malkiel, Y., “El libro infinido de María Rosa Lida de Malkiel: Josefo y su influencia en la literatura española", Filología (Buenos Aires) 13 (1968-69), pp. 205-226.

Martin, G., "El modelo historiográfico alfonsí”, en Id. (ed.), La historia alfonsí: el modelo y sus destinos (siglos XIII-XV), Madrid, Casa de Velázquez, 2000, pp. 9-40.

Montoya Martínez, J., “La norma retórica en la obra de Alfonso X”, en J. Paredes (ed.), Medioevo y Literatura. Actas del V Congreso de la Asociación Hispánica de Literatura Medieval (Granada, 27 septiembre-1 octubre 1993), Granada, Universidad de Granada, 1995, 1, pp. 147-170.

Morreale, M., "Vernacular scripture in Spain”, en G. W. H. Lampe, The Cambridge History of the Bible, Cambridge, Cambridge University Press, 1969, 2. pp. 465492.

Moure Casas, A. M., "Plinio en España: panorama general”, RELat (Revista de estudios latinos) 8 (2008), pp. 203-237.

Nieto IbÁÑez, J. M., “Flavio Josefo en los Antiquitatum Iudaicarum libri IX de Arias Montano", en J. F. Domínguez Domínguez (coord.), Humanae litterae. Estudios de humanismo y tradición clásica en homenaje al profesor Gaspar Morocho Gayo, León, Universidad de León, Secretariado de Publicaciones y Medios Audiovisuales, 2004, pp. 367-380.

Peláez Benítez, M. D., “La leyenda troyana en España”, en Ead., Pedro de Chinchilla. Libro de la historia troyana, Madrid, Editorial Complutense S.A., 1999, pp. 45-58.

Pérez Herranz, F. M., Lindos y tornadizos: El pensamiento filosófico hispano (siglos XVXVII), Madrid, Verbum, 2016.

Perona, J., "Lenguas, traducción y definición en el Scriptorium de Alfonso X", Cahiers de linguistique hispanique médiévale 14-15 (1989), pp. 247-276.

"La obra enciclopédica de Alfonso X", en E. Ramón Trives- H. Provencio Garrigós (eds.), Estudios de lingüística textual: Homenaje al profesor Muñoz Cortés, Murcia, Universidad de Murcia, 1998, pp. 345-358.

Puerto Benito, J. J., The Heroides in Alfonso X's General Estoria: translation, adaptation, use and interpretation of a classical work in a thirteenth-century Iberian History of the world (Tesis), Lexington, Kentucky, 2008.

Rico, F., Alfonso el Sabio y la General estoria: tres lecciones, Barcelona, Ariel, 1972. 
Salvo García, I., "Las Heroidas en la General Estoria de Alfonso X: texto y glosa en el proceso de traducción y resemantización de Ovidio", Cahiers d'Études Hispaniques Medievales, 32 (2009), pp. 205-228.

, “Los mitos de la creación de las Metamorfosis de Ovidio (Met. I, v. 5-162) en la General Estoria de Alfonso X", en M. Castillo Lluch-M. López Izquierdo (eds.), Modelos latinos en la Castilla Medieval, Madrid-Frankfurt, Vervuert Verlagsgesellschaft-Iberoamericana, 2010, pp. 201-222 (2010a).

"La materia ovidiana en la Generalestoria de AlfonsoX:problemas metodológicos en el estudio de su recepción", en J. Gamba Corradine-F. Bautista Pérez (eds.), Estudios sobre la Edad Media, el Renacimiento y la Temprana Modernidad, San Millán de la Cogolla, CiLengua, 2010, pp. 359-369 (2010c).

, Ovidio en la General Estoria de Alfonso X (Tesis), Universidad Autónoma de Madrid, 2012.

, "Ovidio y la compilación de la General estoria", Cahiers d'Études Hispaniques Medievales, 37 (2014), pp. 45-61.

Sánchez-Prieto Borja, P., “El léxico de la General estoria de Alfonso X el Sabio”, Anuario de estudios medievales, 45.1 (2015), pp. 17-53.

Saquero SuÁrez-Somonte, P. - González Rolán, T., “Aproximación a la fuente latina del "Libro de las generaciones de los dioses de los gentiles" utilizada en la General Estoria de Alfonso X el Sabio", Cuadernos de Filología Clásica. Estudios latinos, 4 (1993), pp. 93-111.

Solalinde, A. G., "Intervención de Alfonso X en la redacción de sus obras", Revista de Filología española, 2 (1915), pp. 283-288.

, "El juicio de Paris en el Libro de Alexandre y en la General Estoria", Revista de filología española, 15 (1928), pp. 1-51.

, "Fuentes de la General Estoria de Alfonso el Sabio", Revista de Filología española, 21 (1934), pp. 1-28; 23 (1936), pp. 113-142.

TAYLOR, B., “Alfonso X y Vicente de Beauvois", M. Haro Cortés (coord.), en Literatura y ficción: "estorias", aventuras y poesía en la Edad Media, Valencia, Publications de la Universitat de Valencia, 2015, pp. 447-458. 